\title{
THE GDP PER CAPITA OF THE MEXICAN REGIONS (1895-1930): NEW ESTIMATES*
}

\author{
JOSÉ AGUILAR-RETURETA \\ Universitat de Barcelona ${ }^{\mathrm{a}}$
}

\begin{abstract}
Apart from Appendini (1972) for 1900, there are, so far, no Mexican regional GDP estimates for the period before 1930. The aim of this paper is to fill this gap by presenting new Mexican regional GDP per capita estimates for several benchmark years between 1895 and 1930. The paper presents the methodology and sources used to estimate the new series, compares them with the previous estimates and offers a first long-term picture of Mexican regional per capita GDPs (1895-2010).
\end{abstract}

Keywords: Mexico, regional GDP, regional inequalities, economic history, growth

JEL Code: N16, N96, R11

* Received 6 August 2014. Accepted 29 December 2014. This paper is part of the authors PhD dissertation, carried out under the supervision of Alfonso Herranz-Loncán and Marc Badia-Miró. This research has been funded by the CONACyT scholarship for PhD studies program abroad. The author also wants to acknowledge the financial support received from the Institut Ramon Llull (Generalitat de Catalunya), the research project ECO2012-39169-C03-02 financed by the Spanish Ministry of Economy and Competitiveness, and the Xarxa de Referència d'R + D + I en Economia i Polítiques Públiques financed by the Catalan government. The author is in debt to Alfonso HerranzLoncán and Marc Badia-Miró for their permanent support. The author also thanks the participants at the "First meeting of regional GDPs reconstruction in Latin America, 1890-2010», held at the Universidad de la República (Montevideo), as well as the participants at the " $4^{\text {th }}$ Southern Hemisphere Economic History Summer School», the «PhD students' Seminar» at the University of Barcelona, and the «Seminario Permanente de Historia e Instituciones Económicas» at the Colegio de México. The author is very grateful to Graciela Márquez for her attention and multiple comments on this work during his research stay at the Colegio de Mexico. Finally, he would like to thank Sandra Kuntz and Carlos Marichal for their useful suggestions.

a Department of Economic History and Institutions, Diagonal, 690; 08034 Barcelona, Spain. jaguilre8@alumnes.ub.edu 


\section{RESUMEN}

Hasta ahora, con la excepción de Appendini (1972) para 1900, no existían estimaciones de los PIBs estatales de México para el periodo anterior a 1930. El propósito de este trabajo es llenar este vacío presentando una nueva estimación del PIBs per cápita estatales para una serie de años de referencia entre 1895 y 1930. En el trabajo se exponen la metodología y fuentes utilizadas para las estimaciones, y se comparan éstas con las estimaciones previas disponibles. Para terminar, se presenta una primera imagen de los PIBs per cápita estatales en México en el largo plazo (1895-2010).

Palabras clave: PIB regional, México, Desigualdades Regionales, Historia Económica, Crecimiento

\section{INTRODUCTION}

One of the most persistent characteristics of Latin American economic history is the long-standing regional inequality within countries. The Mexican case is not an exception, since the country has been characterised by high regional inequality at least since the take-off of modern economic growth during the Porfiriato. However, although regional disparities have been well studied for recent years, there is very little evidence for the evolution of aggregate regional inequality in the very long term, in spite of the increasing amount of studies of Mexican economic performance during the period in which the national market was integrated and modern economic growth emerged (1876-1930) ${ }^{1}$. In most cases, investigations for this period with a regional scope are either descriptions of particular

${ }^{1}$ Regional inequality studies including years before 1940 were mainly carried out in the 1970 s and early 1980s (Appendini et al. 1972; Unikel et al. 1978; Hernández 1980). By contrast, with the exception of Ruiz's work (Ruiz 2007, 2010), recent literature has mostly concentrated on the decades after 1940 and, especially, on the period of gradual opening of the economy that started in the early 1980s and was consolidated in 1994, when the NAFTA came into effect (see Hernández 1997; Esquivel 1999; Cermeño 2001; Sánchez-Reaza and Rodríguez-Pose 2002; Chiquiar 2005). These studies have commonly approached Mexican regional income inequality through $\beta$-convergence and $\sigma$-convergence analyses. Broadly speaking, this literature has observed a period of $\beta$ and $\sigma$ convergence between 1940 and 1980, and a divergence period from the 1980s onwards. In addition, some recent studies have applied the New Economic Geography framework to the analysis of Mexican regional inequalities since 1940, during the transition from being a relatively closed economy to a very open one (see Hanson 1996, 1998a, 1998b; Krugman and Livas 1996; Jordaan and Sánchez-Reaza 2006; Hernández 2009; Jordaan and Rodriguez-Oreggia 2012). In accordance with these frameworks, after the economic liberalisation since the 1980s, the backward and forward linkages were not strong enough to support the concentration of production around Mexico City. Instead, these linkages have increasingly been associated with the international market (mainly the US market), resulting in the relocation of manufacturing industry to the northern border regions. 
industries in particular regions, or studies of a specific economic sector across the country. This could respond, to some extent, to the lack of some of the most common indicators of regional economic activity, such as regional GDPs, an absence that has limited our understanding of the reasons for the persistent regional inequality in the country.

This paper seeks to fill this gap by providing a new estimation of the Mexican regional GDPs per capita for the benchmark years 1895, 1900, 1910, 1921 and 1930. For this purpose, national GDP across the Mexican states was disaggregated by adopting, depending on source availability, two different strategies. First, priority was given to regional direct production sources and, second, in those cases for which production data were unavailable, the Geary and Stark (2002) methodology was applied. By linking the new regional GDPs to the existing estimations from 1940s to the present, it has been possible to offer an overview of Mexico's regional economic performance in the long-term (1895-2010). Thus, this new database aims to set up the basis for further investigations, seeking to include the Mexican case into the international literature on the patterns and causes of regional inequality in the very long run ${ }^{2}$.

This is a period of great interest since it was during the agro-export era (1870-1929) when the Mexican economy, like other Latin American countries, took the first steps towards modern economic growth. The primary export activity, led by the mining and agro-exporter sectors, was the main force behind the relatively good economic performance experienced in those years (Kuntz 2014). In fact, the first industrialisation wave that took place in the last years of this period is commonly recognised as an endogenous outcome driven by export-led growth (Haber 2010). Several institutional changes (such as the elimination of domestic trade taxes), together with railroad expansion, encouraged domestic market integration (Dobado and Marrero 2005). This, in turn, intensified regional economic specialisation, which explains to a large extent the performance of the different regional economies over the entire period. The new series show that, with the exception of Mexico City, the states with better economic performance were those which had a greater participation in export activity. Thus, the regional GDP per capita estimates presented in this paper might contribute to a better understanding of both regional and national economic evolution during this historical period.

The structure of this paper is as follows. The next section presents the methodology and sources used to estimate the new regional per capita GDPs in detail. Section 3 presents the new estimates and a comparison with the previously available figures for 1900 (Appendini 1978) and 1930 (Ruiz 2007). In section 4 , a long-run picture of the evolution of the Mexican regional

2 See a useful survey of this literature in Kim (2009) and further studies by Moasterio and Reis (2008); Rosés, Martínez-Galarraga, and Tirado (2010); Henning et al. (2011); Felice (2011); Klein and Crafts (2012); Martínez-Galarraga (2012); Badia-Miró et al. (2012); and Badia-Miró (2014), among others. 
FIGURE 1

THE MEXICAN STATES

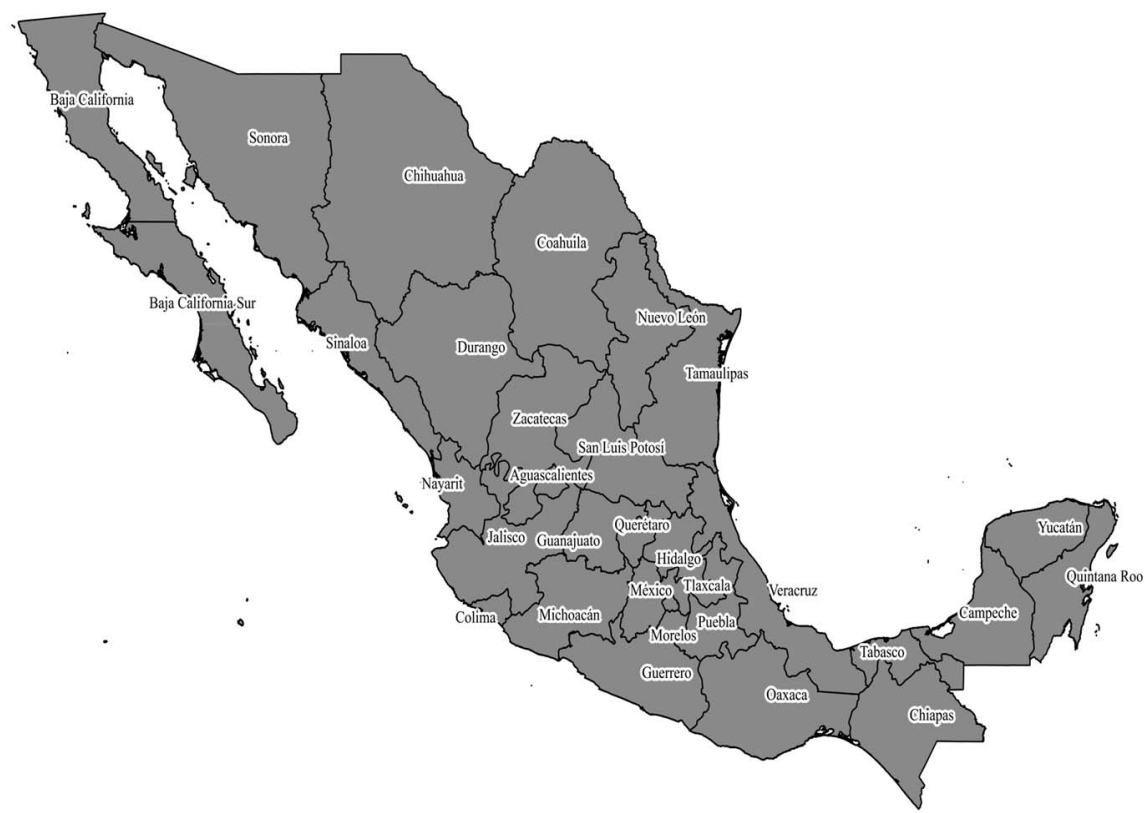

Source: Own elaboration, using QGIS software. Map taken from: www.diva-gis.org

GDPs (1900-2010) is presented by linking the new series to previous estimates. Finally, section 5 concludes. The Mexican states, which are the reference unit of the estimation, are shown in Figure 1.

\section{METHODOLOGY AND SOURCES}

The Instituto Nacional de Estadística y Geografía (INEGI), the Mexican official national institute of statistics, does not have any estimates of the states' GDP for the years before 1970 (INEGI 1985). For previous years, scholars have commonly used the estimations made by Kirsten A. Appendini (1978), either directly or as a basis for new estimations (Esquivel 1999; Germán-Soto 2005; Ruiz 2006, 2007, 2010). Appendini estimated regional GDPs for 1900, 1940, 1950 and 1960 using a homogenous methodology (see Unikel et al. 1978) ${ }^{3}$. The method used by Appendini (1978) consists of

3 The regional GDP presented in Appendini (1978) for 1900 and 1960 had been previously published in Appendini et al. (1972). Moreover, the methodology applied in Appendini (1978) for the 
disaggregating the national output of each sector across states according to the relative participation of each state in certain output indicators, measured at state level.

More recently, Ruiz (2007) offered an alternative estimation of regional per capita GDPs at state level for the years 1930, 1940, 1950, 1960 and 1965. This author uses the series provided by Appendini (1978) as a basis for all his estimates, and applies a very similar estimation methodology (see Ruiz 2006) $)^{4}$.

As previously mentioned, this study aims to estimate regional GDP per capita figures from 1895 to $1930^{5}$. As in previous research, for each sector, the national GDP across states is disaggregated on the basis of several indicators. This implies that, for each sector, the sum of all states' GDPs is equal to the national GDP. As mentioned above, priority is given to direct production sources. Only in those sectors for which there is no direct information, such as industry for the early years and most services for the whole period, is the indirect methodology developed by Geary and Stark (2002) applied.

Geary and Stark's methodology is an indirect estimation technique to distribute national GDP figures among regions, under the assumption of perfect factor mobility and well integrated national markets. This method uses information on relative wages and sectoral shares of employment. The authors assume that each region's sectoral productivity is reflected in its sectoral wage, relative to the national sectoral wage. Thus, a region's sectoral output is sector labour force multiplied by sector labour productivity. GDP in each region is the sum of its sector outputs (Geary and Stark 2002, p. 921).

This methodology has been used in many recent works with a historical scope (Crafts 2005; Felice 2009; Rosés et al. 2010; Henning et al. 2011; Martínez-Galarraga 2012; Badia-Miró et al. 2012) ${ }^{6}$. Following Geary and

(footnote continued)

years 1940 and 1950 is the same that had been previously applied in Appendini et al. (1972) for 1900 and 1960

4 This author has recently published new estimates of the industrial GDP sector at state level from 1930 to 1965 (Ruiz 2014).

5 In 1893, the Dirección General de Estadística published, for the first time, the Anuario Estadístico de la República (Mexican Statistical Yearbook), which involved a substantial quality improvement in national statistics. Moreover, the first national Population Census (Censo Nacional de Población) was published, also by the Dirección General de Estadística, in 1895. In Sandra Kuntz's words: «...[by 1890] not only a wider statistic information is available, but it was also published regularly and under a more uniform criteria» (Kuntz 2002, p. 227, my translation). By contrast, the available information for previous years is much scarcer and makes it much more difficult to estimate regional GDP figures.

6 Among these, it is important to highlight Crafts' (2005) research, which modified the original method by using tax data to allocate non-wage income across regions. Rosés et al. (2010) also introduced a modification to the original method. Those modifications prove the flexibility of this methodology, which facilitates its adaptation to each economy's specific characteristics and source availability. 
Stark (2002, p. 933), regional GDP is defined as

$$
Y=\sum^{i} Y_{i}
$$

where $Y_{i}$ is the state GDP, defined as

$$
Y_{i}=\sum^{j} y_{i j} L_{i j}
$$

$y_{i j}$ and $L_{i j}$ being, respectively, the output per worker and the number of workers in state $i$ and sector $j$. As we have no data for $y_{i j}$ this value is proxied by the product of the national sectoral output per worker $\left(y_{j}\right)$ times the ratio between the state's sectoral wage and the Mexican average wage for this sector $\left(W_{i j} / W_{j}\right)$, under the assumption that each state's labour productivity in each sector is proportional to that state's sectoral wage. Thus, regional GDP is given by

$$
Y_{i}=\sum^{j}\left[y_{j} \beta_{j}\left(\frac{W_{i j}}{W_{j}}\right)\right] L_{i j}
$$

where $y_{j}$ is the national output per worker of sector $j$ and $\beta_{j}$ is defined as a scalar, which preserves the relative state differences but scales the absolute levels so that the state totals for each sector add up to the known national total:

$$
\beta_{j}=\frac{Y_{j}}{\sum^{i}\left[y_{i}\left(\frac{W_{i j}}{W_{j}}\right)\right] L_{i j}}
$$

There is a potential problem involved with the application of this method to the Mexican case, which is associated with the Mexican labour market structure at the time. According to Kuntz:

[during the Porfiriato] although both population and the monetized sector of the economy increased, thousands of people still remained in their rural communities or haciendas as indentured labourers, and rarely participating in the market. [...] In the South, masses of workers were incorporated into coffee and henequen plantations under labour relations that combined some degree of extra-economic coercion with low wage pay. However, it is not possible to estimate the number of workers involved

(Kuntz 2010, p. 327, my translation).

This situation could distort the results due to the underestimation of labour productivity, which might introduce biases in the distribution of national GDP among regions. However, this problem seems to affect mostly 
FIGURE 2

DISTRIBUTION OF THE MEXICAN MANUFACTURING GDP BY STATES IN 1930

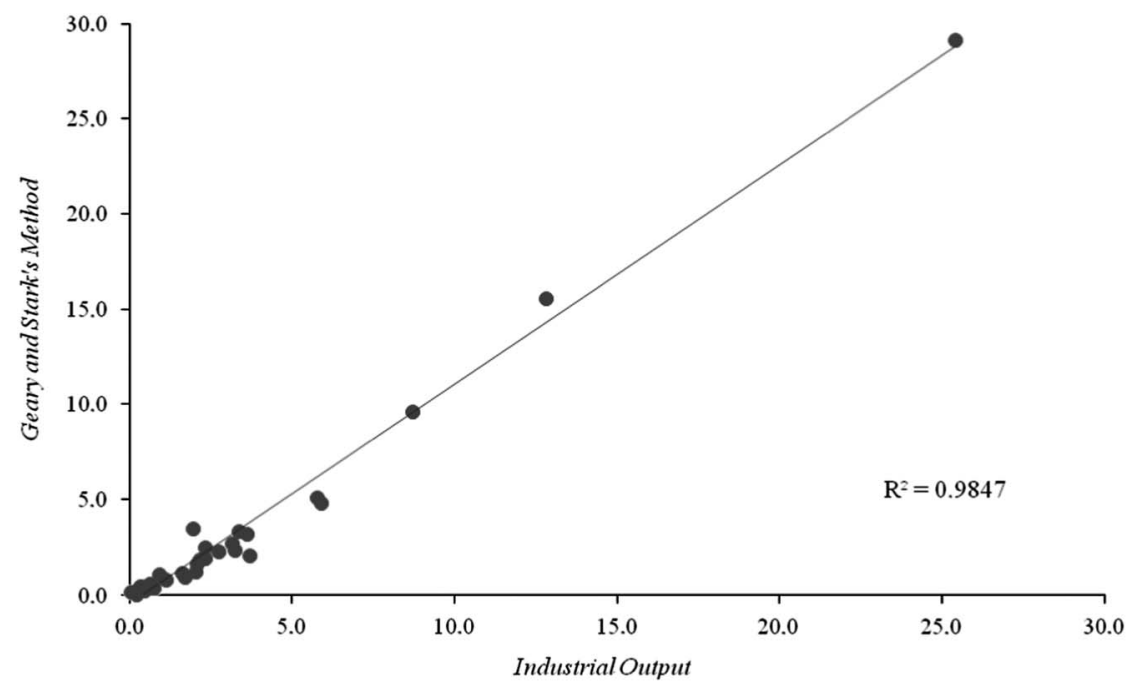

Source: See text.

the primary sector, which is precisely the sector for which direct output information is most abundant and, therefore, where it is not necessary to apply the Geary and Stark methodology. In the case of the secondary and tertiary sectors there is abundant evidence of labour market mobility across regions and sectors, responding to economic incentives such as higher relative wages (Kuntz and Speckman 2011, p. 517). For instance, Aurora Gómez-Galvarriato has found, in the case of the textile industry (the most developed one during the Porfiriato), that: «...In 1893-1896 there existed a strong relationship between these two variables [labour productivity and wages]. (...)» (Gómez-Galvarriato 2002, p. 299). In other words, the Geary and Stark methodology is only applied to the industrial sector and some of the service sectors, which may be assumed to be less seriously affected by labour market rigidities. To prove the robustness of applying this methodology in the estimation, Figures 2 and 3 show the correlation between the states' shares in the 1930 manufacturing output that result from applying both the direct production and Geary and Stark's methodologies ${ }^{7}$. As can be

7 The year 1930 is the first year for which this exercise can be performed because it is the date of the first complete Industrial Census (the previous Industrial Census of 1902 had many information gaps). The figure is based on population data taken from the fifth Census of Population (1930), and industrial wages and output at state level from the 1930 Industrial Census. The shares for each state are presented in Table A1. 
FIGURE 3

DISTRIBUTION OF THE MEXICAN MANUFACTURING GDP BY STATES IN 1930

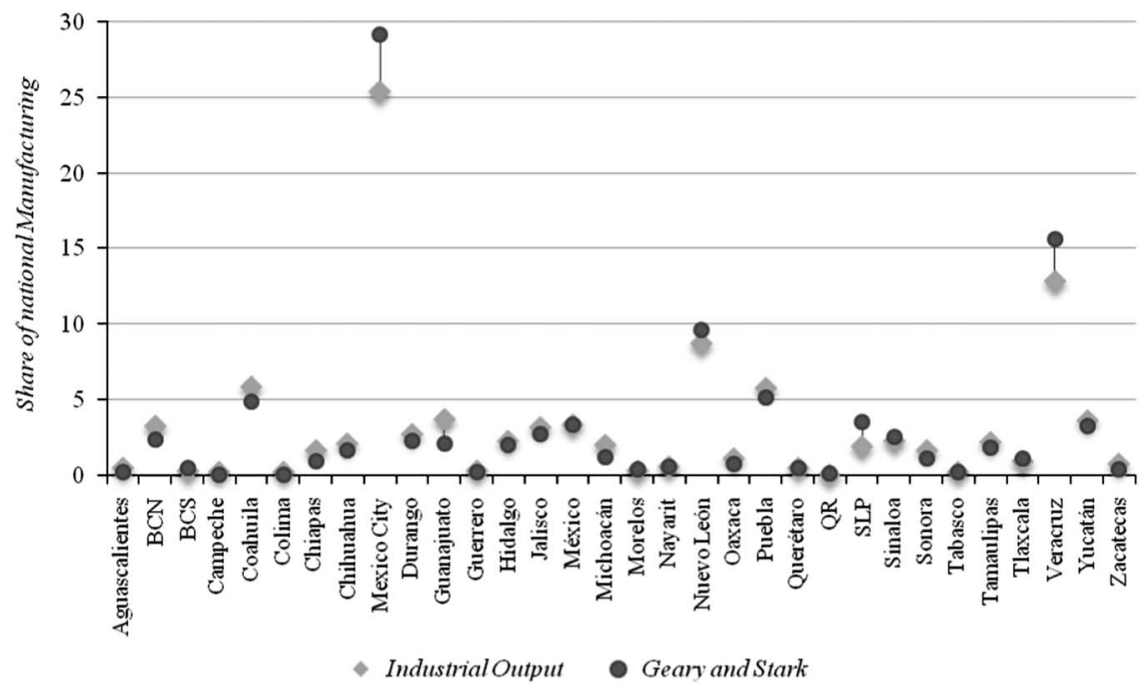

Source: See text.

seen, the correlation between both values is fairly high, suggesting that the use of this methodology for previous years may provide likely results.

Another estimation problem is related with the changes in the Mexican administrative division. During the period under study (1895-1930), the current state of Quintana Roo (which was only established as an autonomous state in 1974) changed its status several times, being considered either as a federal territory or as a part of the Yucatán state. To allow comparability of the estimates over time, it was necessary therefore to include Quintana Roo within the state of Yucatán for the entire period, even in those cases for which data are available for Quintana Roo as an independent state. Furthermore, during this period, the Baja California peninsula (nowadays divided into two autonomous states: Baja California North and Baja California South) was a single federal territory. Therefore, for the period 1895-1930, the peninsula of Baja California is considered a single unit of analysis.

There are two main series of Mexican aggregate GDP for the period under consideration, which were estimated by Enrique Pérez (1960) and Mario Gutiérrez Requenes (1969) and cover the years 1895-1959 and 1895-1967, respectively. Both estimations have been used repeatedly in other works, and the National Institute of Geography and Statistics (INEGI) reproduced Pérez's estimation in the "Estadísticas Históricas de México» (2009). These, in turn, were used by Angus Maddison (1992) and Barro and Ursúa (2008) in 
their databases. On the other hand, Leopoldo Solís used Gutiérrez Requenes' series in his work «La realidad económica mexicana: retrovisión y perspectivas», which has been widely used by Mexican and international scholars (Solís 1970), and the Bank of Mexico also included this series in its database.

As in the case of Appendini et al. (1972), Gutiérrez Requenes' (1969) national GDP series are used for our estimates, for two main reasons. First, Gutiérrez Requenes (unlike Pérez), was explicit regarding both the methodology applied and the sources used for his aggregate GDP estimation. Second, Gutiérrez Requenes' (1969) GDP is disaggregated into thirteen sectors (agriculture, livestock, forestry, fishing, mining, oil, manufacturing, construction, electric energy, transport, government, commerce and others), while Enrique Pérez's GDP is only disaggregated in seven subsectors (agriculture, livestock, mining, oil, manufacturing, transport and other activities). Both reasons are important for this research since, whereas knowing the data and the method used by Gutiérrez Requenes to reconstruct the national GDP allows a more consistent estimation of regional figures, its more detailed disaggregation also allows a more precise distribution of national output. Nevertheless, it is important to stress that both series present very similar trends and fluctuations over the period analysed.

As previously mentioned, the different sectors of Gutiérrez Requenes' national GDP database among states are distributed following different procedures $^{8}$. First, sectoral production was distributed directly, on the basis of output indicators, in the cases of the primary sector (which includes agriculture, livestock, forestry and fishing), mining, oil and commerce. By contrast, the secondary sector (i.e. manufacturing - with the exception of 1930 - construction and electric energy) and services, with the exception of commerce (i.e. transport, government and others), are obtained by using the Geary and Stark (2002) method ${ }^{9}$.

For those sectors in which the estimates are based on production values and depending on the availability of data, information in current or in constant prices is used in each case. Thus, while in agriculture and livestock data in current prices are used for the entire period, in mining and forestry (with the exception of 1930) information is available in constant prices (gold pesos). The estimates of the commerce sector are also constructed using data in constant prices (with the exceptions of 1921 and 1930). When current prices are used, inflation differentials across states could affect the relative participation of each state in the indicator of dispersion. Unfortunately, there

\footnotetext{
8 The national GDP series provided by Gutiérrez Requenes (1969) is expressed in 1950 pesos. Unfortunately, it is not clear whether this series was put together with a structure of prices based on 1 benchmark year for the different sectors, or whether the structure of prices used changed throughout the period.

9 Table A2 presents a summary of the methods used in each benchmark year and each economic sector.
} 
are no index prices at the state level for the entire period that would allow us to correct this issue. This potential distortion is not present when the estimates are based on data in constant (national) prices, or in the oil sector, in which units of production (barrels produced) are used. Finally, it is also absent from those sectors in which the estimates are based on Geary and Stark's methodology (i.e. the secondary sector, with the exception of manufacturing in 1930, and the services sector, with the exception of commerce), although this is dependent on the assumption that differences in wage levels across states reflect productivity differentials. Therefore, it is fairly unlikely that inflation differentials across states change the global estimate's results.

In the next lines the methodology and sources used for each year and each economic sector are described in detail.

\subsection{Primary Sector: Agriculture}

Agriculture is the sector for which quantitative information is most abundant during the period of analysis. For the years 1895, 1900 and 1910, the distribution of the national agriculture output among states is based on the production of twelve products: corn, bean, barley, wheat, sugar cane, cotton, henequen, coffee, tobacco, chickpeas, vanilla and rubber ${ }^{10}$. This sample includes those crops that were relatively important not only at the national level, but also at the state level. Thus, for instance, although henequen production only accounted for a low share of the national production, it was extremely concentrated in one state (Yucatán). According to the Estadísticas Económicas del Porfiriato: Fuerza de trabajo y actividad económica por sectores (1964), these products represented 81.5, 80.8 and 79.9 per cent of the total agricultural production in 1895, 1900 and 1910, respectively. The volume of production is taken from the Mexican Statistical Yearbooks published in those years, and prices come from the Estadísticas Económicas del Porfiriato (at current prices). The prices of corn, wheat and beans are available at state level. For the rest, prices are at national level.

For 1930, the national agricultural output is distributed according to the states' total agriculture production value, taken from the First Census of Agriculture and Livestock of that year. Finally, in the case of 1920 the quantity and quality of the available official statistical data is much worse, due to the Civil War's impact on public institutions during the 1910s and 1920s. Therefore, there are no available data at the state level for most crops, and only some scattered information on some products such as corn, wheat and bean. For this reason, the agriculture values of 1921 are obtained by doing a lineal interpolation of the share corresponding to each state in 1910 and 1930.

10 The 1910 estimates are based on state data for 1907, which is the last year of publication of the Mexican Statistical Yearbooks before 1910. 
It was necessary to introduce some corrections to the raw data. In a few cases, state-level prices of certain crops (such as corn, wheat or bean) were extremely high, distorting the general estimation. In those cases, average prices of the Regional Division to which the state belonged ${ }^{11}$ were taken. Thus, in 1895 and 1900, the prices of corn, wheat and bean in Chiapas and Oaxaca were replaced by the average prices of the South Pacific region, and, also in 1895, the price of corn in Veracruz was replaced by the average price of the Gulf of Mexico region. For 1910, the same correction had to be performed for the prices of corn in Sonora and Campeche, the price of wheat in Guerrero and Sonora, and the price of beans in Chiapas. Due to the absence of prices for Quintana Roo for 1910, the price in Yucatan was applied. Finally, the production data of coffee, vanilla and tobacco in Oaxaca for 1895 (which were surprisingly high) were replaced by the average of the 1894 and 1896 figures, except in the case of vanilla, in which the 1898 figure is used, due to the absence of information for the previous years. The final estimates of state agricultural output can be seen in Table A3.

Some particular states experienced a high variability in agricultural production during the period under study. This was largely related with significant changes in their production structure during the first globalisation. For instance, in Baja California the increase in cotton production provoked an upswing in the state's participation in the national agriculture output from 1910 to 1921 and 1930. Yucatán's share within the national agricultural output also varied widely, due to the fluctuations of henequen production, which was largely concentrated in this state.

\subsection{Livestock}

The only source that provides a complete livestock production database at the state level during the Porfiriato (1876-1910) is the 1902 Livestock Census, which is reproduced in the Estadisticas Económicas del Porfiriato..., and is the main source for our estimates for 1895,1900 and $1910^{12}$. In other words, and due to the scarcity of information for the years 1895-1910, it had to be assumed that the distribution of livestock production across states remained constant throughout the period. It was only possible to take into account price differences among states, at least for some products. In our estimation the production of cattle, pork and milk are considered. Cattle and pork production is measured in kilograms (weighted in carcasses), and milk production in litres. According to the Estadisticas Económicas del Porfiriato... these products represented 89.49, 85.67 and 84.83 per cent in 1897, 1902 and 1907, respectively, of the total livestock production. Cattle

11 The Regional Division proposed in the Estadísticas Económicas del Porfiriato... (1964) is used.

${ }^{12}$ The Statistical Yearbook does not give information on this sector at regional level. 
and pork current prices are available at state level, but milk prices are only available at the national one.

The sources for 1921 and 1930 are the Statistical Yearbook of 1923-1924 and the First Census of Agriculture and Livestock (1930). For 1921 the total value of cattle, pork and goat (in current pesos) in 1924 is taken to distribute the national livestock GDP across states ${ }^{13}$. In the case of 1930, poultry value is also considered. According to the mentioned sources, these products amounted to 79.5 and 83.3 per cent of total production in 1921 and 1930, respectively. Table A4 presents the new estimates of livestock production at state level for all benchmark years.

\subsection{Forestry and Fishing}

Information on forestry is also available in the Statistical Yearbooks for the years 1895 to 1910 . For 1895, tanning bark - in kilograms - is the only possible proxy for production in this sector, and for 1900 and 1910 the production value (in gold pesos) of mahogany, cedar, mesquite, pine and oak is considered. These products represent 74 and 73 per cent of total forestry production in 1900 and 1907, respectively (Estadísticas Económicas del Porfiriato...). As in agriculture, no information is available for forestry around 1920, and the regional distribution of forestry production is assumed to be the same in 1921 and 1930. The source for the 1930 estimation is the First Census of Agriculture and Livestock (1930), which provides the Total Value of Forestry Production (in current pesos) for each state.

Fishing output at the national level is only available from 1921 onwards. This should not be a serious problem, since the share of this sector in the aggregate GDP is very low (0.04 per cent in 1921 and 0.09 per cent in 1930). As no statistical data are available for this sector at the regional level, the fishing production of 1921 and 1930 was distributed among the coastal states, weighted according to each state's population. Table A5 presents the estimates for both forestry and fishing.

\subsection{Mining and Oil}

\subsubsection{Mining}

Mining GDP was distributed among states on the basis of information on the output distribution of both «mines in operation» and «metal production' (excluding the iron and steel industry) ${ }^{14}$. The source for 1895, 1900 and 1910

13 Information before 1924 is too scarce to be used as the basis for the estimation.

14 "Mines in operation» production is the first step of the mining productive chain, and «metal production» corresponds to any subsequent treatment received by metals. «Mines in operation» and 
is the Statistical Yearbook series, which gives production data («Metal Production Total Value» and «Mines Production Value») at state level in gold pesos $^{15}$. The estimation of 1921 involves two steps. First, the share corresponding to «mines in operation» production is taken from the Mining Statistical Year Book of 1923 (Anuario de Estadística Minera, 1923). In this case, the «Production Value» in current pesos of gold, silver, lead and copper is added. These products account for around 85 per cent of the total production of «mines in operation» in 1923. Second, for «metal production», a lineal interpolation of the shares of the years 1910 and $1930^{16}$ is carried out. For the 1930 estimation, the First and Second Industrial Censuses, carried out in 1930 and 1935, respectively, are used. Information on the output of the «mines in operation» is obtained from the 1930 Census, and data on «metal production» come from the 1935 Census («Total Value of production» in current pesos is used $)^{17}$. Table A6 presents the estimation results.

In some cases, the state shares within the national mining output experienced wide fluctuations that can be explained easily. For instance, the high share of Chihuahua in 1930 is explained by the huge production of silver and lead around that year. That share was not exceptional since, in 1927, Chihuahua produced 32 per cent of the national mining production. On the other hand, the downtrend in Guanajuato in the 1920s and 1930s is explained by the deep mining crisis that took place in that state in those decades. Finally, the fluctuations in the Aguascalientes share can be explained by the arrival of the Guggenheim company at the end of the $19^{\text {th }}$ century, which established one of the most modern mining plants in America at a time when capital was fairly unevenly distributed across Mexican states.

\subsubsection{Oil}

Oil production does not appear in national GDP until 1902 (with a very low participation in total production: 0.01 per cent); therefore, this sector is only considered from 1910 onwards. Oil production at state level, in barrel

\footnotetext{
(footnote continued)

«metal production» are added on the basis of the indications of a working paper of the Bank of Mexico (1962) - in which Gutiérrez Requenes developed his estimation - and the mining data presented in the First Industrial Census of 1930.

15 For data availability reasons, information on 1898, 1899 and 1907 for 1895, 1900 and 1910 is used. The only exception is Chihuahua in 1900, for which the 1900 figure is used due to the improbably high level of the 1899 data.

16 The ratio between the output of the "mines in operation» and «metal production» subsectors is assumed to be the average of the ratios of 1910 and 1930.

17 The Gutiérrez Requenes (1969) national index prices are used in order to account for the effect of inflation. Thus, 1930 and 1935 values are converted to 1930 pesos. The reason why the effect of inflation is accounted for is because the output of «mines in operation» in 1930 and the output of «metal production» in 1935 are given in current prices (1930 and 1935 prices, respectively). Therefore, if the inflation effect is not considered, the "metal production» output component in 1935 could be overestimated in 1930 .
} 
units, comes from Brown (1993), the Statistical Yearbook of 1923-1924 and the First Industrial Census (1930), for the years 1910, 1921 and 1930, respectively. Table A7 shows the oil production share at state level; as can be seen, oil production in those years was mostly located in Veracruz.

\subsection{Secondary Sector}

In the case of the secondary sector, the indirect Geary and Stark (2002) method was applied in order to distribute the national GDP across states, with the only exceptions of manufacturing and electric energy in 1930. As previously mentioned, this methodology requires, in addition to the national sectorial output, two main variables: labour force and wages, by economic sector and at the national and regional levels ${ }^{18}$. In this regard, it was only possible to consider male workforce data, due to the serious biases involved in the available industrial female labour figures ${ }^{19}$. This means, according to the Geary and Stark methodology, that the population share and the productivity of the female workforce in each state are assumed to be the same (relative to the national average) as that of the male workforce ${ }^{20}$.

\subsection{Manufacturing}

For 1895, 1900 and 1910, manufacturing labour force data are obtained from the First, Second, and Third Mexican Population Censuses published by Dirección General de Estadística, and wages come from Estadisticas Económicas del Porfiriato... (1964). Actually, for these years wages are only available for the following macro-regions, which include several states: North, Gulf of Mexico, North Pacific, South Pacific and Centre ${ }^{21}$. For the

18 The methodological refinement proposed by Crafts (2005) to the Geary and Stark methodology (2002), in which capital income is considered in addition to wage income, cannot be tested in the Mexican case due to the absence of an industrial tax database at state level in the entire period. However, Geary and Stark (2014) have proved that their «untreated» methodology generates accurate estimates of regional GDP for the UK case. The authors also make some criticisms of Crafts' method.

19 This bias problem is illustrated in Graphs A1 and Graph A2, in the Appendix. These graphs present the share of both male and female workforce over total population at state level. Graph A.2 shows the highly unlikely rises and falls of the female workforce registered in each state from one census to the next over the period under study. Moreover, the available evidence on female industrial workers is also implausible when considered in absolute and relative terms. For instance, according to the First Mexican Population Census, in 1895 the number of women employed in the industrial sector in the state of Chiapas was twice as high as in Mexico City (the specific numbers are 28,830 , i.e. 17.43 per cent of Chiapas' total female population vs. 14,976 , i.e. 5.96 per cent of Mexico City's total female population), a situation that is not consistent at all with the Mexican historiography. This, in turn, reflects the lack of homogeneity over time and across states in the definition criteria of the census.

20 The same reasoning could be applied to child labour.

21 The macro-regions are composed as follows. North: Coahuila, Chihuahua, Durango, Nuevo León, San Luis Potosí, Tamaulipas and Zacatecas. Gulf of Mexico: Campeche, Quintana Roo, 
1921 estimation, labour force comes from the Fifth Mexican Population Census and each state's relative wage is obtained as a weighted average of the relative wages of 1910 and 1930 (the latter are taken from the First Industrial Census, 1930 $)^{22}$. Finally, the 1930 estimation is taken directly from the First Industrial Census (1930), which provides the total value of production and inputs. Table A8 shows the estimates for this sector.

\subsection{Construction and Electricity}

Construction and electricity sector estimates are obtained by applying the Geary and Stark methodology for all years, with the exception of the electricity sector in 1930, for which production data from the First Industrial Census are used. The male workforce is taken from the Population Censuses of $1895,1900,1910$ and $1940^{23}$. For 1921, the same workforce structure across states as in 1910 is assumed (because the Population Census of 1920 does not provide disaggregated data of these sectors). On the other hand, wages in the construction and electricity sectors are assumed to be the same as in manufacturing. Table A9 shows both estimations.

\subsection{Services: Government, Transport, Others}

Government, transport and others services' regional GDPs are also obtained by applying the Geary and Stark methodology. The male workforce for the three subsectors comes from the corresponding Population Censuses $(1895,1900,1910,1921$ and 1930). In the case of government, the population employed in «public services» and «armed forces» for the years 1895, 1900 and 1910 is added, while for 1921 and 1930 «public administration» workers are added. Government wages at state level come from two sources: Estadísticas Económicas del Porfiriato... from 1895 to 1910 - for which a

\footnotetext{
(footnote continued)

Tabasco, Veracruz and Yucatán. North Pacific: Baja California, Sinaloa, Sonora and Tepic. South Pacific: Colima, Chiapas, Guerrero and Oaxaca. Centre: Aguascalientes, Distrito Federal, Guanajuato, Hidalgo, Jalisco, México, Michoacán, Morelos, Puebla, Querétaro and Tlaxcala. In the case of Nuevo León, the wages of the highest-wage region are always applied to account for the particular characteristics of that state's industry, which was one of the most modern in the country throughout the period (see, for instance: Haber, 1989; Cerutti, 1992; Marichal and Cerutti, 1997; Kuntz, 2010).

${ }_{22}$ A weighting of two-thirds is given to the wages of 1910 and one-third to those of 1930 . This means that the structure of manufacturing productivity in 1920 is assumed to have been closer to that of 1910 than to that of 1930. This is based on recent evidence suggesting that the impact of the Revolution on the industrial sector was not destructive. Instead, with the exception of a few years of the 1910 decade (from 1914 to 1917), the modern industrial sector experienced relatively intense and sustained growth between 1910 and 1930. In fact, Haber (2010, p. 432) shows that during this period not only did the number of total firms increase, but also the industrial installed capacity (approached by the machinery import) grew substantially.

${ }^{23}$ The Population Census of 1930 does not offer, at state level, the workforce of the construction sector.
} 
weighted average of «public services» and «armed forces» wages is estimated and the Statistical Yearbooks of 1930 for wages in 1921 and 1930 - in these years, wages in the "executive power» sector are used.

For the transport sector data on the workforce in "communications and transports» are used, and the male workforce of «other services» is the sum of «professionals» and «other services» workers in 1895, 1900 and 1910, and the sum of "free professions» and "non-specific occupations» workers in 1921 and 1930. As no wage data are available for these subsectors, wages are assumed to be the same in all regions. This means assuming equal labour productivity in those sectors across all states. The estimation results for these three subsectors are presented in Table A10.

\subsection{Commerce}

In the case of commerce - the only service subsector for which a direct production indicator is available - a direct estimation is carried out on the basis of data on «declared sales» at state level. This information comes from the Fiscal Statistics Bulletins (1895, 1900 and 1910), and the Bulletins of National Statistics (1921 and 1930). The «declared sales» data is based on the stamp duty - which was a federal tax with the same specifications across all states. Due to the scarcity of information, the «declared sales» of 1918 and 1924 are used to estimate the 1921 and 1930 figures, respectively. The final results are shown in Table A11.

\section{MEXICAN REGIONAL PER CAPITA GDPs, 1895-1930}

\subsection{The New Estimates: A Global Overview}

Figure 4 shows the per capita GDP estimates of the Mexican regions between 1895 and 1930 . These results are fairly consistent with the economic history literature and show that Mexican regional inequality was very high from the first stages of the process of national market integration. Regional disparities become even clearer when the states are grouped in macro-regions, showing the longterm differences between the north and the south of the country (see Table 1).

In some regions, relative per capita GDP experienced wide fluctuations over time. This is the case, for instance, of Aguascalientes, which started with a GDP per capita of 1.06 in 1895 - always considering the national average as the unit of reference - increased to 2.65 in 1900, and ended with a GDP per capita of 0.88 in 1930. Although such processes will be analysed and explained in detail in further research, the relatively fast process of structural change in certain regions - such as the mining production areas - and some external shocks (such as international demand fluctuations or movements in the prices of some exportable agrarian and mining commodities) could largely explain these cases of high instability. 
FIGURE 4

REGIONAL GDP PER CAPITA IN MEXICO 1895-1930 (MEXICO = 1)

1895

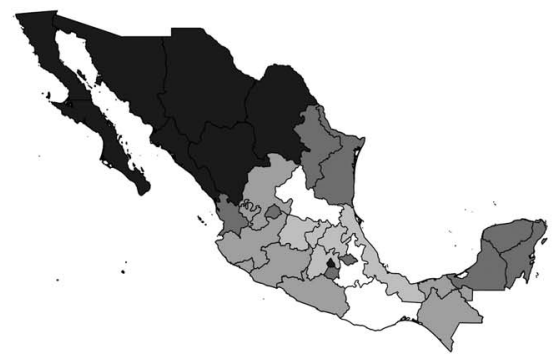

1910

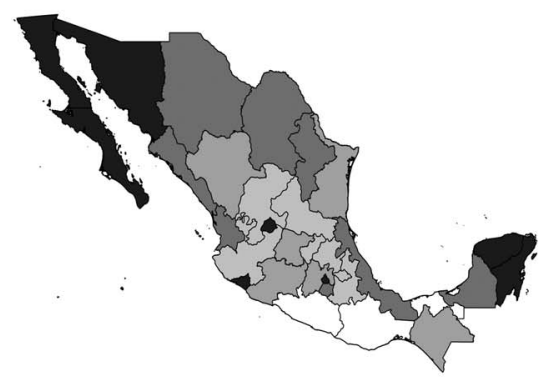

1930

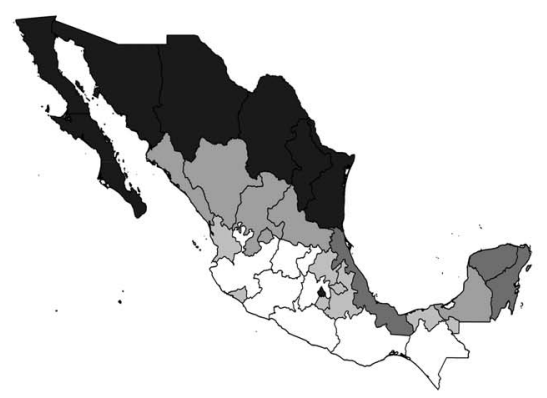

1900

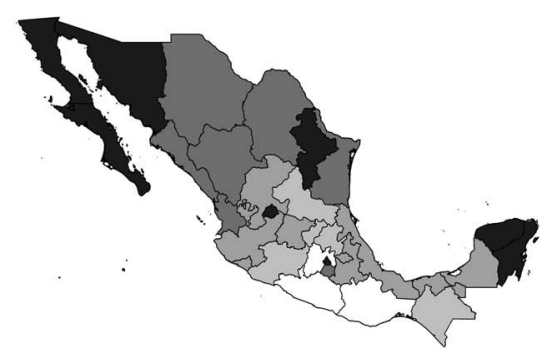

1921

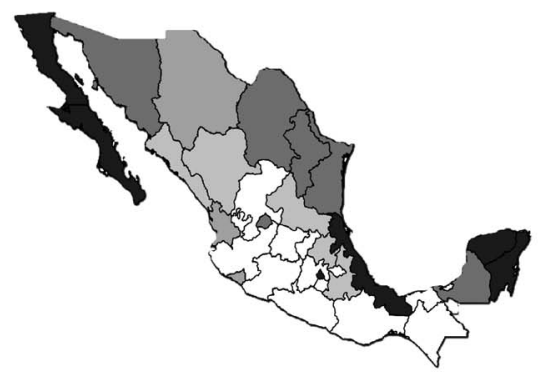

GDP pc. $M x=1$

$\square 4.40-1.52$

$\square$ 1.51- 1.03

$\square 1.02-0.82$

$0.81-0.68$

$0.67-0.25$

Note: The intervals displayed in the legend are obtained as follows: the relative values estimated for all years are put together and ranked from the highest to the lowest in order to construct one single vector. Finally, this vector was divided into five groups with the same number of observations.

Source: See text.

Moving to the sector level, Table 2 shows the spatial distribution of Mexican manufacturing GDP from 1895 to 1960. The spatial distribution of this sector has often been identified as one of the most important explanatory 
TABLE 1

REGIONAL PER CAPITA GDP IN MEXICO, 1895-1930 (Mexico = 1)

\begin{tabular}{|c|c|c|c|c|c|}
\hline & 1895 & 1900 & 1910 & 1921 & 1930 \\
\hline Mexico City & 2.68 & 2.61 & 2.46 & 2.53 & 2.71 \\
\hline North & 1.94 & 1.71 & 1.53 & 1.45 & 2.21 \\
\hline Baja California & 3.63 & 3.11 & 2.28 & 2.62 & 4.4 \\
\hline Chihuahua & 1.93 & 1.29 & 1.39 & 1.02 & 1.82 \\
\hline Coahuila & 1.64 & 1.46 & 1.4 & 1.05 & 1.72 \\
\hline Nuevo León & 1.25 & 1.6 & 1.28 & 1.28 & 1.66 \\
\hline Sonora & 2.11 & 1.79 & 1.93 & 1.26 & 1.77 \\
\hline Tamaulipas & 1.06 & 1.03 & 0.91 & 1.5 & 1.9 \\
\hline Pacific-North & 1.3 & 1.22 & 1.19 & 0.78 & 0.77 \\
\hline Colima & 1.02 & 0.91 & 1.52 & 0.89 & 0.8 \\
\hline Jalisco & 0.95 & 0.98 & 0.71 & 0.61 & 0.55 \\
\hline Nayarit & 1.38 & 1.51 & 1.42 & 0.84 & 0.78 \\
\hline Sinaloa & 1.85 & 1.46 & 1.11 & 0.79 & 0.93 \\
\hline Centre-North & 1.13 & 1.25 & 1.23 & 0.83 & 0.89 \\
\hline Aguascalientes & 1.17 & 2.13 & 2.62 & 1.22 & 0.88 \\
\hline Durango & 1.78 & 1.32 & 0.86 & 0.69 & 0.97 \\
\hline San Luis Potosí & 0.65 & 0.68 & 0.71 & 0.73 & 0.84 \\
\hline Zacatecas & 0.92 & 0.86 & 0.71 & 0.67 & 0.85 \\
\hline Gulf of Mexico & 1.04 & 1.14 & 1.31 & 1.55 & 1.03 \\
\hline Campeche & 1.41 & 0.98 & 1.11 & 1.21 & 0.88 \\
\hline Tabasco & 0.91 & 0.83 & 0.62 & 0.46 & 0.68 \\
\hline Veracruz & 0.71 & 0.97 & 1.03 & 2.66 & 1.26 \\
\hline Yucatán & 1.11 & 1.77 & 2.47 & 1.85 & 1.3 \\
\hline Centre & 0.87 & 0.86 & 0.82 & 0.62 & 0.65 \\
\hline State of Mexico & 0.71 & 0.64 & 0.9 & 0.6 & 0.54 \\
\hline Guanajuato & 0.78 & 0.82 & 0.83 & 0.57 & 0.62 \\
\hline
\end{tabular}


TABLE 1 (Cont.)

\begin{tabular}{|l|c|c|c|c|c|}
\hline & $\mathbf{1 8 9 5}$ & $\mathbf{1 9 0 0}$ & $\mathbf{1 9 1 0}$ & $\mathbf{1 9 2 1}$ & $\mathbf{1 9 3 0}$ \\
\hline Hidalgo & 0.78 & 0.79 & 0.68 & 0.68 & 0.79 \\
\hline Puebla & 0.66 & 0.87 & 0.73 & 0.68 & 0.7 \\
\hline Querétaro & 0.78 & 0.76 & 0.76 & 0.66 & 0.51 \\
\hline Tlaxcala & 1.13 & 0.84 & 0.79 & 0.61 & 0.68 \\
\hline Morelos & 1.27 & 1.28 & 1.04 & 0.54 & 0.72 \\
\hline South & 0.75 & 0.6 & 0.7 & 0.42 & 0.4 \\
\hline Chiapas & 0.85 & 0.74 & 0.86 & 0.54 & 0.5 \\
\hline Guerrero & 0.82 & 0.41 & 0.56 & 0.26 & 0.28 \\
\hline Michoacán & 0.83 & 0.77 & 0.87 & 0.56 & 0.49 \\
\hline Oaxaca & 0.48 & 0.46 & 0.51 & 0.32 & 0.31 \\
\hline Mexico (1950 pesos) & 513.2 & 606.29 & 768.45 & 786.4 & 938.81 \\
\hline Yearly growth rate (\%) & & 3.33 & 2.37 & 0.21 & 1.97 \\
\hline
\end{tabular}

Source: See text.

factors of the evolution of Mexican regional inequality, at least since the middle of the $20^{\text {th }}$ century. The table shows that, while the centre region went through a process of de-industrialisation throughout the period, the north and the capital regions became more industrialised. Moreover, the coefficient of variation suggests that manufacturing spatial dispersion started to increase at least since the 1910s.

This would partially contradict some recent research, in which the process of concentration of industry in Mexico City has been assumed to have started with the ISI policies. Nevertheless, our new estimates suggest that this process of manufacturing concentration began well before the import-substituting industrialisation period (although it accelerated significantly after 1930).

\subsection{Comparison With Previous Estimates}

As previously mentioned, there are no previous regional GDP figures available for Mexico for the years 1895, 1910 and 1921. So far, the estimates by Appendini (1972) and Ruiz (2007) are the only Mexican regional per capita GDPs available for the years 1900 and 1930 (see section 2). Thus, it is only 
TABLE 2

SPATIAL DISTRIBUTION OF MEXICAN MANUFACTURING GROSS VALUE ADDED (percentage)

\begin{tabular}{|l|c|c|c|c|c|c|c|c|}
\hline Region & $\mathbf{1 8 9 5}$ & $\mathbf{1 9 0 0}$ & $\mathbf{1 9 1 0}$ & $\mathbf{1 9 2 1}$ & $\mathbf{1 9 3 0}$ & $\mathbf{1 9 4 0}$ & $\mathbf{1 9 5 0}$ & $\mathbf{1 9 6 0}$ \\
\hline Capital & 17.5 & 15.9 & 17.1 & 23.2 & $\mathbf{2 8 . 8}$ & 40.2 & 37.4 & 49.4 \\
\hline North Gulf & 4.2 & 3.9 & 5.3 & 8.2 & 10.8 & 9.6 & 9.6 & 9.7 \\
\hline North & 3.0 & 5.1 & 5.6 & 5.2 & 8.0 & 7.9 & 12.3 & 6.0 \\
\hline North Pacific & 7.0 & 6.6 & 7.9 & 7.5 & 8.0 & 4.9 & 6.4 & 5.5 \\
\hline Centre Gulf & 5.0 & 5.7 & 7.0 & 9.0 & 13.0 & 4.4 & 7.5 & 5.5 \\
\hline Centre Pacific & 21.1 & 21.0 & 15.5 & 12.5 & 5.3 & 5.5 & 6.1 & 7.3 \\
\hline Centre & 28.0 & 26.0 & 22.6 & 19.9 & 13.4 & 12.3 & 9.3 & 8.7 \\
\hline Centre North & 8.5 & 8.6 & 9.9 & 7.2 & 5.7 & 11.2 & 6.7 & 3.1 \\
\hline Peninsula & 2.2 & 2.6 & 3.0 & 3.2 & 3.8 & 1.9 & 2.4 & 2.5 \\
\hline South Pacific & 3.4 & 4.7 & 5.8 & 4.2 & 3.1 & 2.2 & 2.4 & 2.2 \\
\hline CV & 1.1 & 1.0 & 0.9 & 1.2 & 1.5 & 2.1 & 1.9 & 2.3 \\
\hline
\end{tabular}

The regions are composed by the following states. Capital: Estado de México, Mexico City; North Gulf: Nuevo León, Tamaulipas; North: Chihuahua, Coahuila; North Pacific: Baja California Norte, Baja California Sur, Sonora, Sinaloa, Nayarit; Centre Gulf: Veracruz, Tabasco; Centre Pacific: Jalisco, Michoacán, Colima; Centre: Guanajuato, Querétaro, Hidalgo, Tlaxcala, Puebla, Morelos; Centre North: Aguascalientes, Durango, Zacatecas, San Luis Potosí; Peninsula: Yucatán, Quintana Roo, Campeche; South Pacific: Guerrero, Oaxaca, Chiapas. The coefficient of variation (CV) was obtained by considering the percentages at the state levels.

Source: From 1895 to 1930: own estimates; from 1940 to 1960: Ruiz (2014).

possible to carry out a comparison of our estimates for these 2 years. Table 3 compares our figures for 1900 with those of Appendini.

Broadly speaking, the position and the values of each region are quite similar. Nevertheless, there are some remarkable differences in the cases of Baja California - in this case, the main difference is not the position but the GDP level - Aguascalientes, Morelos, Jalisco, Tlaxcala, San Luis Potosí and the state of Mexico. There are other less significant differences, such as the cases of Chihuahua, Sinaloa, Tamaulipas, Tlaxcala and Guanajuato. In order to identify the reasons for the main differences, Table 4 compares Appendini's estimates with our figures at sectoral level ${ }^{24}$.

\footnotetext{
24 The shares of the primary sector are not compared because both estimations are based on the same sources and methodology and, therefore, the resulting estimates are very similar.
} 
TABLE 3

COMPARISON OF 1900 REGIONAL GDP PER CAPITA $($ Mexico $=1)$

\begin{tabular}{|c|c|c|c|}
\hline \multicolumn{2}{|c|}{ New estimates } & \multicolumn{2}{|c|}{ Appendini (1972) } \\
\hline Baja California & 3.11 & Mexico City & 2.68 \\
\hline Mexico City & 2.61 & Baja California & 2.62 \\
\hline Aguascalientes & 2.13 & Morelos & 2.01 \\
\hline Sonora & 1.79 & Durango & 1.98 \\
\hline Yucatán & 1.77 & Sonora & 1.9 \\
\hline Nuevo León & 1.60 & Yucatán & 1.88 \\
\hline Nayarit & 1.51 & Chihuahua & 1.85 \\
\hline Sinaloa & 1.46 & Nuevo León & 1.7 \\
\hline Coahuila & 1.46 & Coahuila & 1.56 \\
\hline Durango & 1.32 & Aguascalientes & 1.53 \\
\hline Chihuahua & 1.29 & Nayarit & 1.44 \\
\hline Morelos & 1.28 & Sinaloa & 1.18 \\
\hline Tamaulipas & 1.03 & Veracruz & 1.14 \\
\hline Jalisco & 0.98 & Tlaxcala & 1.06 \\
\hline Campeche & 0.98 & Colima & 1.04 \\
\hline Veracruz & 0.97 & Zacatecas & 1.01 \\
\hline Colima & 0.91 & Campeche & 0.94 \\
\hline Puebla & 0.87 & Tamaulipas & 0.92 \\
\hline Zacatecas & 0.86 & Puebla & 0.87 \\
\hline Tlaxcala & 0.84 & Tabasco & 0.84 \\
\hline Tabasco & 0.83 & San Luis Potosí & 0.81 \\
\hline Guanajuato & 0.82 & Jalisco & 0.79 \\
\hline Hidalgo & 0.79 & México & 0.76 \\
\hline Michoacán & 0.77 & Hidalgo & 0.68 \\
\hline Querétaro & 0.76 & Querétaro & 0.65 \\
\hline Chiapas & 0.74 & Guanajuato & 0.65 \\
\hline
\end{tabular}


TABLE 3 (Cont.)

\begin{tabular}{|l|l|l|c|}
\hline \multicolumn{2}{|c|}{ New estimates } & \multicolumn{2}{c|}{ Appendini (1972) } \\
\hline San Luis Potosí & 0.68 & Chiapas & 0.64 \\
\hline México & 0.64 & Michoacán & 0.61 \\
\hline Oaxaca & 0.46 & Guerrero & 0.39 \\
\hline Guerrero & 0.41 & Oaxaca & 0.33 \\
\hline
\end{tabular}

Source: See text.

When GDP figures are disaggregated among sectors, the differences between both estimations increase significantly. As can be observed in the table, the main differences arise in both mining and manufacturing. The differences in the mining sector result from the fact that, in the new estimation, the production values of «mines in operation» and "metal production" are considered from the Statistical Yearbooks, whereas Appendini's estimates only take into account the distribution of the former, from the same source.

In the case of manufacturing, differences can be explained because, whereas for our estimate the Geary and Stark (2002) method was applied, Appendini (1972) used the industrial production data taken from the Industrial Census of 1902 (DGE 1903). The main problem of using the Industrial Census is that it seems to be highly biased due to the exclusion of the traditional manufacturing production, and the absence of many industrial establishments. Therefore, the representativeness of this census is rather low and uneven across states, causing high distortions in the estimation. As is pointed out in the introductory part of the census:

The industry in Mexico is very widespread; there is a great amount of self-employed persons working at a very small scale, and this has undoubtedly caused that it was not possible to obtain enough data, and that countless cases of concealing happened, so only limited data supplied by some important industrial establishments were available. (...) For these reasons, it will be seen that only the data that have been possible to collect are published, and surely there are many more industrial establishments than the ones enumerated in this work... .

(DGE 1903, p. ii, my translation)

This problem also shows up when observing the industrial workforce registered in the Industrial Census, which amounts to just 24 per cent of the total industrial workforce recorded in the Population Census of 1900. This introduces biases at state level. For instance, the manufacturing workforce 


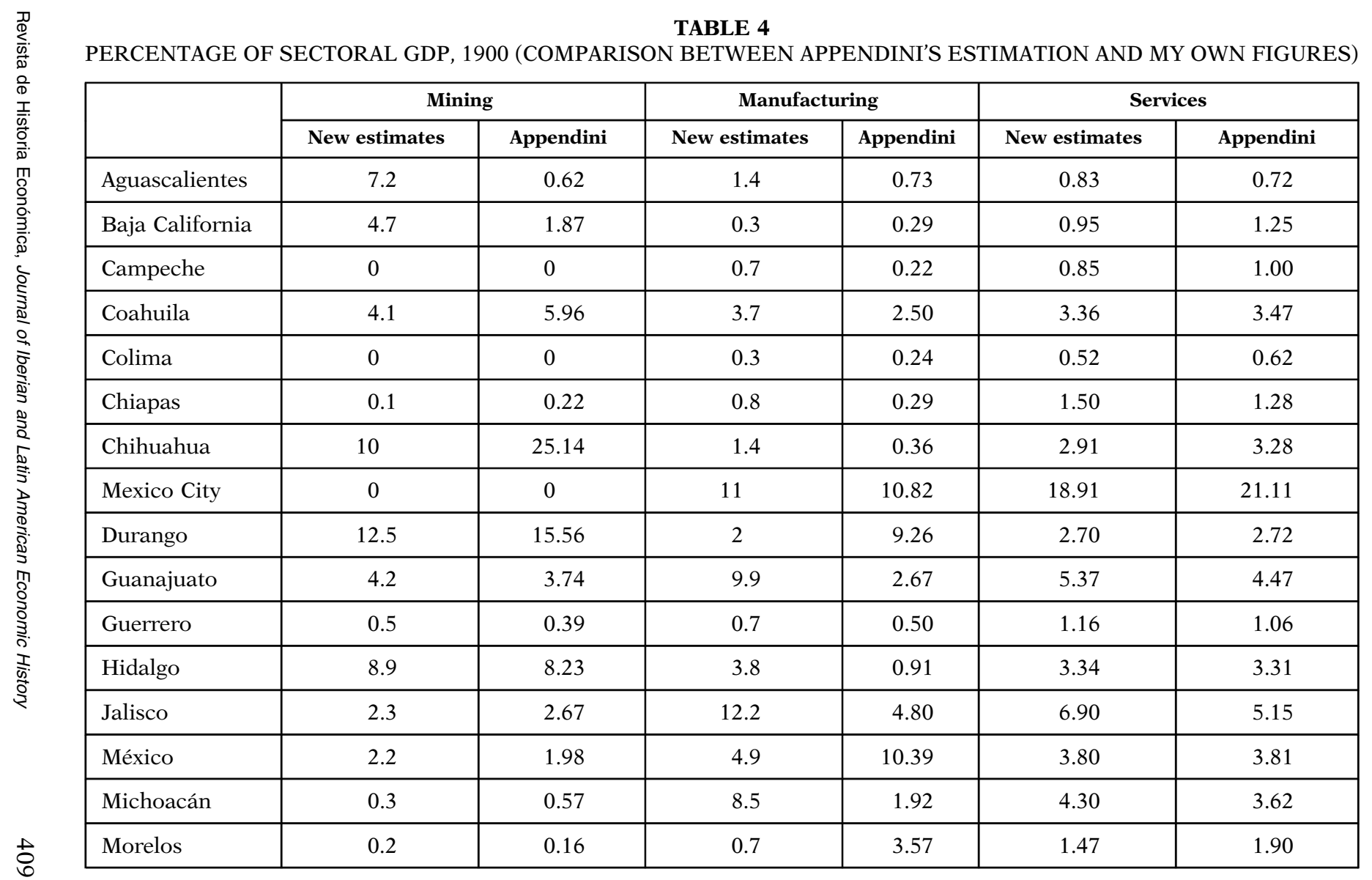


TABLE 4 (Cont.)

\begin{tabular}{|c|c|c|c|c|c|c|}
\hline & \multicolumn{2}{|c|}{ Mining } & \multicolumn{2}{|c|}{ Manufacturing } & \multicolumn{2}{|c|}{ Services } \\
\hline & New estimates & Appendini & New estimates & Appendini & New estimates & Appendini \\
\hline Nayarit & 0.7 & 0.74 & 1.4 & 0.96 & 1.02 & 1.00 \\
\hline Nuevo León & 11.3 & 1.18 & 3 & 12.48 & 4.89 & 3.04 \\
\hline Oaxaca & 0.6 & 0.83 & 3.2 & 1.42 & 3.00 & 2.78 \\
\hline Puebla & 0.6 & 1.01 & 7.8 & 7.15 & 5.98 & 6.38 \\
\hline Querétaro & 0.2 & 0.10 & 2.2 & 0.88 & 1.39 & 1.38 \\
\hline San Luis Potosí & 7.5 & 5.12 & 2.7 & 5.88 & 3.07 & 3.03 \\
\hline Sinaloa & 5.9 & 6.24 & 3.2 & 1.88 & 2.66 & 2.55 \\
\hline Sonora & 7.7 & 9.27 & 1.7 & 2.29 & 2.65 & 2.57 \\
\hline Tabasco & 0 & 0 & 0.6 & 0.39 & 1.12 & 0.99 \\
\hline Tamaulipas & 0.1 & 0.07 & 0.9 & 0.05 & 2.28 & 2.20 \\
\hline Tlaxcala & 0 & 0 & 1.6 & 2.04 & 1.07 & 1.17 \\
\hline Veracruz & 0 & 0 & 5.1 & 9.86 & 6.82 & 8.38 \\
\hline Yucatán & 0 & 0 & 1.9 & 1.68 & 2.56 & 3.12 \\
\hline Zacatecas & 8.2 & 8.32 & 2.5 & 3.58 & 2.62 & 2.64 \\
\hline Total & 100 & 100 & 100 & 100 & 100 & 100 \\
\hline
\end{tabular}

Source: See text. 
listed in the 1902 Industrial Census for the states of Guanajuato and Nayarit correspond to 6.2 and 92.45 per cent, respectively, of that registered in the Population Census of 1900.

By contrast, differences in the share of services between the two estimates are minor. This is because the weight of commerce within the services sector is very high (around 51 per cent) and, for this subsector, both sets of figures have used the same proxy (declared sales) to distribute the national commerce output across states ${ }^{25}$.

Finally, a comparison between our estimates and the 1930 figures proposed by Ruiz (2007, p. xxix) is shown in Table 5. Once again, the differences are minor when total state values are considered. Ruiz's data allow comparisons of the two estimates for the industrial sector (Table 6). As shown in the table, while manufacturing estimates are fairly close, the construction subsector presents wider differences. This could be explained because Ruiz assumed equal productivity across states, while we applied the Geary and Stark method (see previous section).

\section{THE REGIONAL GDP PER CAPITA IN MEXICO. A LONG-TERM PICTURE (1895-2010)}

To link these new regional per capita GDP estimates for the years 1895-1930 with those available for 1940-2010, German-Soto's (2005) GDP figures for 19402000, and the INEGI estimates for 2010 are used as well as the corresponding National Population Censuses to express GDP in per capita terms ${ }^{26}$. In order to account for the extreme spatial concentration of oil production, the states' GDP for 1940-2010 excluding oil production was also estimated. From 1940 to 1960, the percentage of each state's oil production is taken from Ruiz (2007) and, for 1970-2010, it is available in INEGI $(1985,2002,2014)$. These figures can be linked to our own estimates without oil production for the period before 1940, obtaining as a result two state GDP databases, with and without the oil sector, for the whole period 1895-2010 (Table 7).

Table 7 shows the high persistence of the states ranked in the extreme positions, especially in the case of the poorest ones which, in turn, are

25 Actually, Appendini (1976) used this proxy to distribute the whole national «service» sector output across states. This is why, in Appendini's estimation, areas with relatively high levels of commercial activity have a higher proportion of total services, such as Mexico City (D.F.) and the state of Veracruz (in which one of the largest Mexican ports is located).

26 Esquivel (2002) offers alternative GDP per capita estimates for the same period. We preferred to use German-Soto (2005) because he presents an «un-treated» GDP per capita database, unlike Esquivel (2002), in which GDP per capita figures are presented with some "corrections» related to the allocation of oil production. Thus, using German-Soto (2005) makes it possible to apply the same method as this author for the entire period (1895-2010) in order to offer a supplementary database without oil production (see text). Nevertheless, both series present very similar trends and distribution patterns among regions over the long run. Figures of 2010 GDP per capita at state level are available at: www.inegi.org.mx/est/contenidos/proyectos/cn/pibe/tabulados.aspx 
TABLE 5

GDP PER CAPITA, 1930 (COMPARISON BETWEEN RUIZ'S FIGURES AND AGUILARRETURETA (highest value $=100)$ )

\begin{tabular}{|c|c|c|c|}
\hline \multicolumn{2}{|c|}{ New estimates } & \multicolumn{2}{|c|}{ Ruiz (2007) } \\
\hline Baja California & 100.0 & Baja California N & 100.0 \\
\hline Mexico City & 38.4 & Mexico City & 33.9 \\
\hline Tamaulipas & 25.2 & Sonora & 25.0 \\
\hline Chihuahua & 24.9 & Tamaulipas & 24.7 \\
\hline Sonora & 24.8 & Nuevo León & 20.7 \\
\hline Coahuila & 23.9 & Coahuila & 20.0 \\
\hline Nuevo León & 22.0 & Baja California S & 19.6 \\
\hline Veracruz & 17.8 & Yucatán & 17.2 \\
\hline Yucatán & 16.8 & Chihuahua & 16.5 \\
\hline Mexico & 13.9 & Quintana Roo & 15.0 \\
\hline Durango & 13.8 & Veracruz & 13.9 \\
\hline Sinaloa & 13.1 & Sinaloa & 13.5 \\
\hline Aguascalientes & 12.7 & Durango & 11.8 \\
\hline Zacatecas & 11.8 & Mexico & 11.4 \\
\hline Colima & 11.6 & Hidalgo & 11.2 \\
\hline Campeche & 11.5 & Colima & 9.8 \\
\hline San Luis Potosí & 11.4 & San Luis Potosí & 9.7 \\
\hline Nayarit & 11.0 & Morelos & 8.9 \\
\hline Hidalgo & 10.6 & Nayarit & 8.2 \\
\hline Puebla & 10.0 & Campeche & 7.2 \\
\hline Morelos & 10.0 & Puebla & 6.5 \\
\hline Tabasco & 9.5 & Jalisco & 6.5 \\
\hline Tlaxcala & 9.4 & Zacatecas & 6.5 \\
\hline Guanajuato & 8.9 & Aguascalientes & 6.5 \\
\hline Querétaro & 8.0 & Tabasco & 6.0 \\
\hline Jalisco & 7.6 & State of Mexico & 5.9 \\
\hline
\end{tabular}


TABLE 5 (Cont.)

\begin{tabular}{|l|l|l|c|}
\hline \multicolumn{2}{|c|}{ New estimates } & \multicolumn{2}{c|}{ Ruiz (2007) } \\
\hline State of México & 7.5 & Guanajuato & 5.8 \\
\hline Michoacán & 6.9 & Tlaxcala & 5.7 \\
\hline Chiapas & 6.6 & Chiapas & 5.3 \\
\hline Oaxaca & 4.2 & Michoacán & 4.8 \\
\hline Guerrero & 4.0 & Querétaro & 4.4 \\
\hline & & Guerrero & 2.8 \\
\hline & & Oaxaca & 2.2 \\
\hline
\end{tabular}

The comparison is presented in this form because there is no other figure available in Ruiz (2007). Source: See text.

concentrated in the centre and south of the country. In contrast, Mexico City and the northern regions have always remained in the top places. Although this pattern will be explained in detail in forthcoming research, this persistence could be mainly explained by the economic specialisation of each state, with the north region and Mexico City having an economic structure with a relatively higher productivity due to a higher presence of manufacturing activity (see Table 2).

The rank ratio displayed at the bottom of Table 7 (which indicates the ratio between the per capita GDPs of the richest and poorest states), reached its maximum value at the end of the agro-export model (1930), when the richest state (Baja California) had a GDP per capita (with and without oil production) that was ca. 15.7 times as large as the poorest state's per capita GDP in the same year (Guerrero). The ratio substantially decreased thereafter, reaching its minimum level at the end of the ISI period, in 1980.

In order to provide a more complete perspective of regional income inequality trends in the long run, Figure 5 depicts the standard deviation (with and without oil production) and the Theil index (without oil production) of the Mexican states' GDP per capita ${ }^{27}$. Both indexes have often been used to test $\sigma$ convergence ${ }^{28}$. As can be seen in the graph, both indicators follow a fairly similar $\mathrm{N}$-shape trend over the period, in which trend changes

27 From now on, the regional GDP per capita database without oil production is used. This is mainly because, as several scholars have highlighted (see Esquivel, 1999; Sánchez-Reaza and Rodríguez-Pose, 2002), Mexican oil production is highly concentrated in few states, causing potential significant biases in regional inequality trends.

${ }^{28} \sigma$ convergence may be defined as a reduction of income dispersion between economies over time (see e.g. Barro and Sala-I-Martín, 1991). 
TABLE 6

PERCENTAGE OF SECTORAL GDP, 1930 (COMPARISON BETWEEN RUIZ'S FIGURES AND AGUILAR-RETURETA)

\begin{tabular}{|c|c|c|c|c|}
\hline & \multicolumn{2}{|c|}{ Manufacturing } & \multicolumn{2}{|c|}{ Construction } \\
\hline & New estimates & Ruiz & New estimates & Ruiz \\
\hline Aguascalientes & 0.4 & 0.45 & 0.2 & 1.08 \\
\hline Baja California & 3.5 & 3.65 & 2.4 & 0.65 \\
\hline Campeche & 0.2 & 0.20 & 0.1 & 0.60 \\
\hline Coahuila & 5.9 & 6.27 & 4.1 & 3.10 \\
\hline Colima & 0.2 & 0.17 & 0.1 & 0.50 \\
\hline Chiapas & 1.7 & 1.96 & 0.5 & 3.72 \\
\hline Chihuahua & 2.1 & 1.63 & 2.2 & 3.06 \\
\hline Mexico City & 25.4 & 25.01 & 48.00 & 20.87 \\
\hline Durango & 2.7 & 3.00 & 0.7 & 1.32 \\
\hline Guanajuato & 3.7 & 3.80 & 1.3 & 3.65 \\
\hline Guerrero & 0.3 & 0.28 & 0.2 & 1.38 \\
\hline Hidalgo & 2.3 & 1.80 & 1.7 & 2.99 \\
\hline Jalisco & 3.1 & 3.21 & 2.8 & 8.64 \\
\hline México & 3.4 & 3.25 & 2.7 & 4.03 \\
\hline Michoacán & 2 & 1.89 & 0.9 & 5.22 \\
\hline Morelos & 0.3 & 0.35 & 0.7 & 0.87 \\
\hline Nayarit & 0.6 & 0.67 & 0.4 & 1.18 \\
\hline Nuevo León & 8.7 & 8.98 & 9.4 & 3.84 \\
\hline Oaxaca & 1.1 & 1.23 & 0.3 & 2.25 \\
\hline Puebla & 5.7 & 5.89 & 5.2 & 7.27 \\
\hline Querétaro & 0.5 & 0.45 & 0.3 & 0.94 \\
\hline San Luis Potosí & 1.9 & 2.07 & 2.6 & 3.58 \\
\hline Sinaloa & 2.3 & 2.49 & 1.6 & 1.97 \\
\hline Sonora & 1.6 & 1.33 & 1.3 & 1.97 \\
\hline Tabasco & 0.2 & 0.22 & 0.2 & 0.74 \\
\hline
\end{tabular}


TABLE 6 (Cont.)

\begin{tabular}{|l|c|c|c|c|}
\hline \multirow{2}{*}{} & \multicolumn{2}{|c|}{ Manufacturing } & \multicolumn{2}{c|}{ Construction } \\
\cline { 2 - 5 } & New estimates & Ruiz & New estimates & Ruiz \\
\hline Tamaulipas & 2.1 & 1.88 & 1.4 & 2.07 \\
\hline Tlaxcala & 0.9 & 1.06 & 0.7 & 1.27 \\
\hline Veracruz & 12.8 & 12.28 & 6 & 5.97 \\
\hline Yucatán & 3.6 & 3.84 & 1.8 & 3.45 \\
\hline Zacatecas & 0.7 & 0.46 & 0.2 & 1.80 \\
\hline Total & 100 & 100 & 100 & 100 \\
\hline
\end{tabular}

Mexico City's high share in construction (48\%) in 1930 would be consistent with this region having $83.2 \%$ of the total construction output in 1960, according to the VII Industrial Census (1960).

Source: See text.

generally coincide with changes in economic model. To start with, during the agro-export model, dispersion increased, reaching its maximum level during the 1930s. Thereafter, as has been shown by previous literature, it gradually declined during the ISI period, from 1940 to 1980 (Esquivel 1999; Ruiz 2010). However, the trend was reversed again from 1980 onwards, when Mexico started a process of increasing openness (Sánchez-Reaza and Rodríguez-Pose 2002; Chiquiar 2005). Income dispersion (excluding oil production) would have stopped its growth in the first decade of the $21^{\text {th }}$ century, although we still do not have a long enough perspective to know whether this change will be sustained ${ }^{29}$.

The long-term trend of Mexican regional income inequality does not seem very different from those observed in Britain (Crafts and Mulatu 2005), France (Combes et al. 2011), Portugal (Badia-Miró et al. 2012) or Spain (Rosés et al. 2010). In contrast, the Mexican experience has been rather different from the Chilean experience (the other Latin American economy for which similar data are available; Badia-Miró 2014). In Chile, there has been a continuous process of regional convergence from the late $19^{\text {th }}$ century to the present. The reasons behind the difference between these two economies will be the subject of future research.

In order to complement the $\sigma$-convergence analysis, Figure 6 tests unconditional $\beta$ convergence for both the entire period (1895-2010) and the

29 Since 2000, there has been a third boom in the oil industry, largely concentrated in the state of Campeche and, to a lesser degree, in the state of Veracruz, both located in the Gulf of Mexico (see Table 7). This high geographical concentration explains the significant increase in dispersion since 2000, when oil production is included. 
TABLE 7

REGIONAL PER CAPITA GDP IN MEXICO: 1900, 1930, 1950, 1980 AND 2010 (Mexico = 1)

\begin{tabular}{|c|c|c|c|c|c|c|c|c|c|}
\hline & 1900 & 1930 & $1930^{1}$ & 1950 & $1950^{1}$ & 1980 & $1980^{1}$ & 2010 & $2010^{1}$ \\
\hline Mexico City & 2.61 & 2.71 & 2.83 & 2.63 & 2.71 & 1.91 & 2.00 & 2.27 & 2.39 \\
\hline North & 1.71 & 2.21 & 2.27 & 1.59 & 1.64 & 1.19 & 1.25 & 1.22 & 1.27 \\
\hline Baja California & 3.11 & 4.40 & 4.54 & 2.87 & 2.96 & 1.28 & 1.34 & 1.03 & 1.08 \\
\hline Baja California S & nd & nd & nd & 1.18 & 1.22 & 1.27 & 1.33 & 1.11 & 1.16 \\
\hline Chihuahua & 1.29 & 1.82 & 1.89 & 1.41 & 1.45 & 0.94 & 0.99 & 1.04 & 1.09 \\
\hline Coahuila & 1.46 & 1.72 & 1.78 & 1.28 & 1.33 & 1.15 & 1.20 & 1.31 & 1.37 \\
\hline Nuevo León & 1.60 & 1.66 & 1.71 & 1.57 & 1.62 & 1.58 & 1.65 & 1.90 & 1.97 \\
\hline Sonora & 1.79 & 1.77 & 1.82 & 1.56 & 1.61 & 1.08 & 1.14 & 1.05 & 1.11 \\
\hline Tamaulipas & 1.03 & 1.90 & 1.85 & 1.28 & 1.31 & 1.03 & 1.08 & 1.12 & 1.08 \\
\hline Pacific-North & 1.22 & 0.77 & 0.79 & 0.81 & 0.84 & 0.85 & 0.89 & 0.88 & 0.93 \\
\hline Colima & 0.91 & 0.8 & 0.82 & 0.83 & 0.85 & 0.91 & 0.95 & 1.01 & 1.06 \\
\hline Jalisco & 0.98 & 0.55 & 0.57 & 0.71 & 0.74 & 1.01 & 1.06 & 1.01 & 1.06 \\
\hline Nayarit & 1.51 & 0.78 & 0.80 & 0.74 & 0.77 & 0.71 & 0.74 & 0.65 & 0.69 \\
\hline Sinaloa & 1.46 & 0.93 & 0.96 & 0.95 & 0.98 & 0.76 & 0.79 & 0.85 & 0.90 \\
\hline Centre-North & 1.25 & 0.89 & 0.91 & 0.62 & 0.64 & 0.64 & 0.67 & 0.85 & 0.89 \\
\hline Aguascalientes & 2.13 & 0.88 & 0.91 & 0.46 & 0.48 & 0.79 & 0.83 & 1.10 & 1.16 \\
\hline Durango & 1.32 & 0.97 & 1.00 & 0.75 & 0.78 & 0.72 & 0.76 & 0.86 & 0.90 \\
\hline San Luis Potosí & 0.68 & 0.84 & 0.83 & 0.70 & 0.71 & 0.58 & 0.61 & 0.79 & 0.83 \\
\hline Zacatecas & 0.86 & 0.85 & 0.88 & 0.55 & 0.57 & 0.47 & 0.49 & 0.63 & 0.66 \\
\hline
\end{tabular}




\begin{tabular}{|c|c|c|c|c|c|c|c|c|c|}
\hline Gulf of Mexico & 1.14 & 1.03 & 0.97 & 1.10 & 1.06 & 1.18 & 0.82 & 1.72 & 0.96 \\
\hline Campeche & 0.98 & 0.88 & 0.91 & 0.84 & 0.87 & 0.76 & 0.80 & 4.39 & 1.17 \\
\hline Tabasco & 0.83 & 0.68 & 0.70 & 0.57 & 0.59 & 2.51 & 0.58 & 1.41 & 0.71 \\
\hline Quintana Roo & nd & nd & nd & 1.93 & 1.99 & 1.20 & 1.25 & 1.28 & 1.35 \\
\hline Veracruz & 0.97 & 1.26 & 0.91 & 1.28 & 0.97 & 0.72 & 0.73 & 0.68 & 0.67 \\
\hline Yucatán & 1.77 & 1.30 & 1.34 & 0.87 & 0.90 & 0.72 & 0.75 & 0.84 & 0.88 \\
\hline Centre & 0.86 & 0.65 & 0.68 & 0.50 & 0.52 & 0.73 & 0.76 & 0.76 & 0.80 \\
\hline Guanajuato & 0.82 & 0.54 & 0.65 & 0.46 & 0.48 & 0.65 & 0.68 & 0.84 & 0.88 \\
\hline Hidalgo & 0.79 & 0.62 & 0.83 & 0.43 & 0.45 & 0.66 & 0.69 & 0.61 & 0.64 \\
\hline Morelos & 1.28 & 0.79 & 0.74 & 0.79 & 0.81 & 0.77 & 0.80 & 0.77 & 0.81 \\
\hline Puebla & 0.87 & 0.7 & 0.72 & 0.53 & 0.55 & 0.65 & 0.68 & 0.69 & 0.73 \\
\hline Querétaro & 0.76 & 0.51 & 0.53 & 0.41 & 0.43 & 0.86 & 0.90 & 1.14 & 1.20 \\
\hline State of Mexico & 0.64 & 0.68 & 0.56 & 0.51 & 0.53 & 0.97 & 1.02 & 0.72 & 0.76 \\
\hline Tlaxcala & 0.84 & 0.72 & 0.70 & 0.37 & 0.38 & 0.55 & 0.58 & 0.53 & 0.55 \\
\hline South & 0.60 & 0.40 & 0.41 & 0.40 & 0.41 & 0.59 & 0.52 & 0.51 & 0.53 \\
\hline Chiapas & 0.74 & 0.50 & 0.52 & 0.40 & 0.42 & 0.87 & 0.50 & 0.44 & 0.44 \\
\hline Guerrero & 0.41 & 0.28 & 0.29 & 0.40 & 0.41 & 0.53 & 0.56 & 0.52 & 0.55 \\
\hline Michoacán & 0.77 & 0.49 & 0.51 & 0.42 & 0.44 & 0.55 & 0.58 & 0.63 & 0.66 \\
\hline Oaxaca & 0.46 & 0.31 & 0.32 & 0.36 & 0.37 & 0.40 & 0.42 & 0.45 & 0.48 \\
\hline Rank ratio & 7.59 & 15.71 & 15.66 & 7.97 & 8.00 & 6.28 & 4.76 & 9.98 & 5.43 \\
\hline
\end{tabular}


FIGURE 5

STANDARD DEVIATION AND THEIL INDEX OF MEXICAN STATES GDP PER CAPITA, 1895-2010

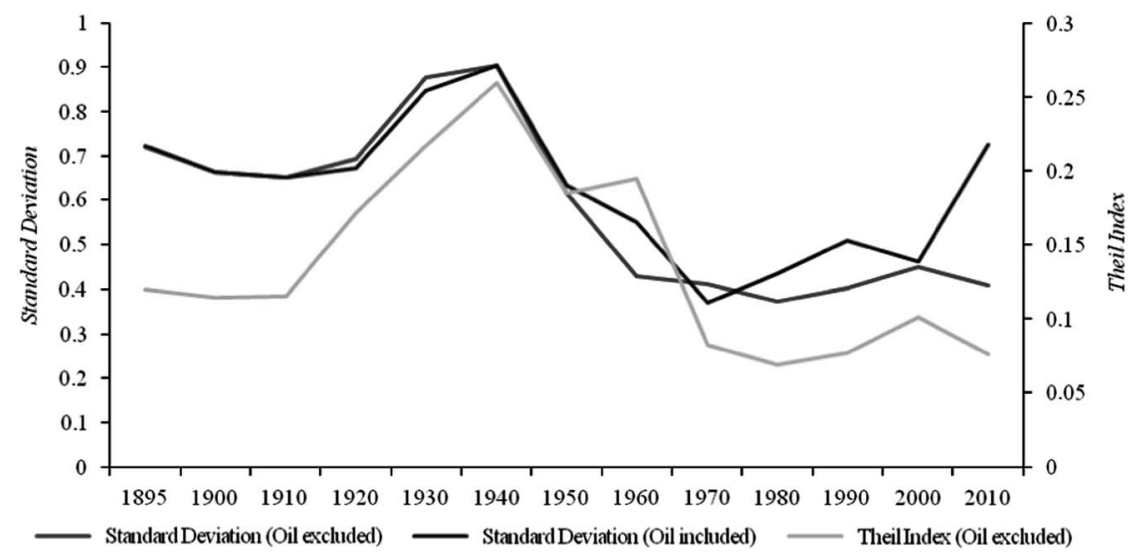

time span of our new estimates (1895-1930) ${ }^{30}$. The results are very different. Figure 6A shows clear evidence of unconditional $\beta$ convergence across Mexican states in the long term. By contrast, in Figure 6B the $\beta$-convergence hypothesis must be rejected for the period 1895-1930, given the lack of correlation between initial per capita GDP and the growth rate. Future research will also focus on the forces behind convergence (or its absence) in different periods.

\section{CONCLUSIONS}

So far, the only available estimates of Mexican regional GDPs for the period before 1940 were those of Appendini (1972) for 1900 and Ruiz (2007) for 1930. This paper has presented the methodology, sources and results of a new regional GDP per capita estimation in Mexico for the benchmark years $1895,1900,1910,1921$ and 1930. The new evidence suggests that the regional disparities between the north and south of the country can be traced back at least to the early stages of the integration of national markets. These disparities widened between 1895 and 1930, due to a large extent to the progress in the industrialisation of the capital and northern regions, and the de-industrialisation of the centre regions. As a result, it was during the 1930s, at the end of the export-led growth episode of Mexican history, when

30 Unconditional $\beta$ convergence is defined as a negative correlation between the income per capita growth rate and the initial level of income per capita for a sample of economies in a particular interval of time (Barro and Sala-I-Martín, 1991). 
FIGURE 6

(A) MEXICAN UNCONDITIONAL $\beta$ CONVERGENCE AT THE STATE LEVEL, 1895-2010. (B) MEXICAN UNCONDITIONAL $\beta$ CONVERGENCE AT THE STATE LEVEL, 1895-1930

(a)

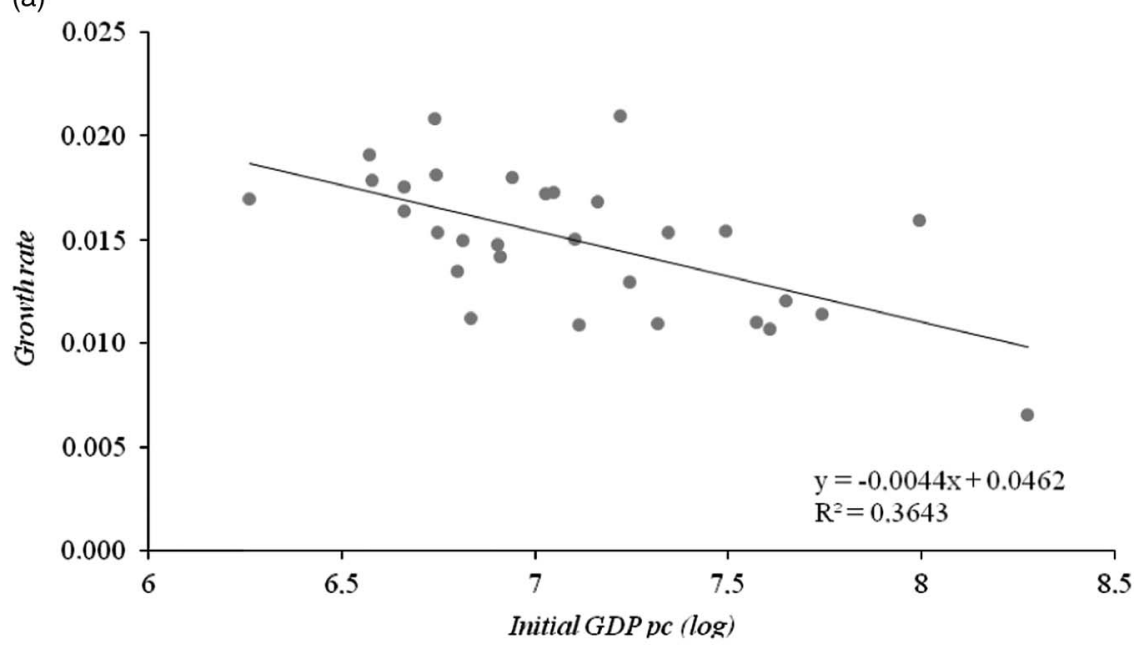

(b)

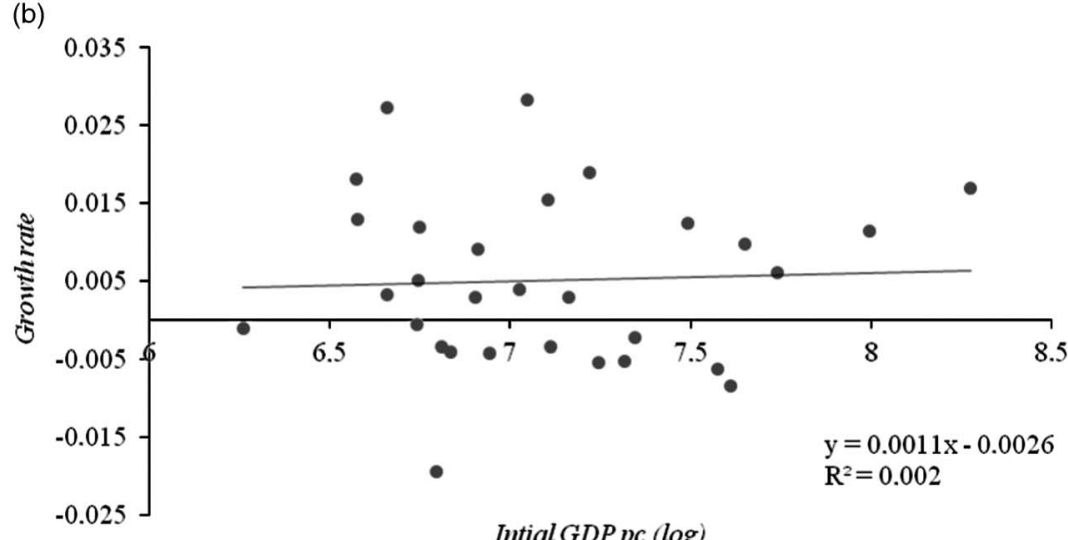

Intial GDP pc (log)

the country's regional inequality reached the maximum level. Thereafter, inequality started a sustained decrease that coincided with the ISI period, until a new increase in inequality started in the 1980s, largely associated with increasing economic openness.

Future research will focus on the patterns and causes of spatial inequalities in Mexico over the long term. Even though regional inequality has been well studied, scholars have focused on recent periods (and 
especially on the transition from a relatively closed economic model to an open one, between 1980 and the present). These new estimates will make it possible to study the inverse process that took place since the interwar period, that is, when the economy changed from a relatively open model to a relatively closed one. Moreover, these analyses will provide us with the necessary tools to answer some relevant questions, such as: What are the causes behind the evolution of regional income inequality in Mexico during the period of national market integration and early industrialisation? Do the theoretical assumptions of the New Economic Geography apply for the Mexican case in the long term? Are the mechanisms behind Williamson's inverted-U hypothesis confirmed for a non-core economy? The answers to these questions may contribute to the international literature on historical regional inequality, providing evidence, unlike most available literature, on an economy outside the Western core.

\section{SUPPLEMENTARY MATERIAL}

To view supplementary material for this article, please visit http://dx.doi. org/10.1017/S0212610915000117

\section{REFERENCES}

APPENDINI, K. (1978): «Producto interno bruto por entidades federativas 1900, 1940, 1950 y 1960». El Colegio de México, mimeographed.

Appendini, K.; Murayama, D., and Domínguez, R. M. (1972): «Desarrollo desigual en México, 1900-1960». Demografía y Economía 16, pp. 1-40.

Badia-Miró, M. (2014): «The Evolution of the Localization of Economic Activity in Chile in the Long Run: A Case of Extreme Concentration». Paper presented in the 4th Latin American Economic History Congress (CLADHE), Colombia.

Badia-Miró, M.; Guilera, J., and Lains, P. (2012): «Regional Incomes in Portugal: Industrialisation, Integration and Inequality, 1890-1980». Revista de Historia Económica 30, pp. 225-244.

Barro, R., and Sala-I-Martín, X. (1991): "Convergence Across States and Regions». Brooking Papers on Economic Activity 1, pp. 107-182.

Barro, R., and Ursúa, J. (2008): Macroeconomic Crisis Since 1870 Mimeo, Cambridge: Harvard University.

Brown, J. (1993): Oil and Revolution in Mexico Berkeley: The University of California Press.

Cermeño, R. (2001): «Decrecimiento y convergencia de los estados mexicanos. Un análisis de panel». El Trimestre Económico 272, pp. 603-629.

Cerutti, M. (1992): Burguesía, capitales e industria en el Norte de México: Monterrey y su ámbito regional, 1850-1910 México: Alianza.

Chiquiar, D. (2005): "Why Mexico's Regional Income Convergence Broke Down». Journal of Development Economics 77, pp. 257-275.

Combes, P.; Lafourcade, M.; Thisse, J., and Toutain, J. (2011): «The Rise and Fall of Spatial Inequalities in France: A Long-Run Perspective». Explorations in Economic History 48, pp. 243-271. 
Crafts, N. (2005): «Regional GDP in Britain, 1871-1911: Some Estimates». Scottish Journal of Political Economy 52, pp. 54-64.

Crafts, N., and Mulatu, A. (2005): «What Explains the Location of Industry in Britain, 1871-1931?». Journal of Economic Geography 5, pp. 499-518.

Dobado, R., and Marrero, G. (2005): «Corn Market Integration in Porfirian Mexico». The Journal of Economic History 65, pp. 103-128.

Esquivel, G. (1999): «Convergencia Regional en México, 1940-1995». El Trimestre Económico LXVI (264), pp. 725-761.

Esouivel, G. (2002): «New Estimates of Gross State Product in Mexico, 1940-2000». México: El Colegio de México, mimeographed.

Felice, E. (2009): «Regional Value Added in Italy (1891-2001): Estimates, Elaborations». Working Papers in Economic History. Spain: Universidad Carlos III de Madrid.

Felice, E. (2011): «Regional Value Added in Italy, 1891-2001, and the Foundation of a Long-Term Picture». The Economic History Review 64 (3), pp. 929-950.

Geary, F., and Stark, T. (2002): «Examining Ireland's Post-Famine Economic Growth Performance». The Economic Journal 112 (482), pp. 919-935.

GEARY, F., and StaRK, T. (2014): «Regional GDP in the UK, 1861-1911: New Estimates». The Economic History Review. Available at http://doi.wiley.com/10.1111/1468-0289.12061

Germán-Soto, V. (2005): «Generación del Producto Interno Bruto mexicano por entidad federativa, 1940-1992». El Trimestre Económico LXXII (287), pp. 617-653.

Gómez-GalvarRiato, A. (2002): «Measuring the Impact of Institutional Change in Capital-Labor Relations in the Mexican Textile Industry, 1900-1930», in J. Bortz, and S. Haber (eds), The Mexican Economy, 1870-1930. Essays on the Economic History of Institutions, Revolution, and Growth. Stanford: Stanford University Press, pp. 289-323.

GutiéRrez Requenes, M. (1969): «Producto Interno Bruto y Series Básicas 1895-1967». Banco de México, Mexico City, mimeographed.

HABER, S. (1989): Industry and Underdevelopment: The Industrialization of Mexico, 1890-1940 California: Stanford University Press.

Haber, S. (2010): «Mercado Interno, Industrialización y Banca, 1890-1929», in S. Kuntz, (ed.), Historia Económica General de México: de la Colonia a nuestros día. Mexico: El Colegio de México, pp. 411-436.

Hanson, G. (1996): «Localization Economies, Vertical Integration and Trade». American Economic Review 86, pp. 1266-1278.

Hanson, G. (1998a): «Regional Adjustment to Trade Liberalization». Regional Science and Urban Economics 28, pp. 419-444.

Hanson, G. (1998b): «North American Economic Integration and Industry Location». Oxford Review of Economic Policy 14, pp. 30-44.

Henning, M.; Enflo, K., and Andersson, F. (2011): «Trends and Cycles in Regional Economic Growth. How Spatial Differences Shaped the Swedish Growth Experience from 1860-2009». Explorations in Economic History 48, pp. 538-555.

HeRnÁNDEZ, D. (2009): «Liberalización Comercial y Localización Industrial en México». University of Barcelona, Spain, PhD Dissertation.

HERNÁNDEZ, E. (1980): «Economías externas y el proceso de concentración regional de la industria en México». El Trimestre Económico 47, pp. 119-157.

Hernández, E. (1997): «Perspectivas del desarrollo regional en México frente la globalización». Economía, Teoría y Práctica 7, pp. 79-106.

JordaAn, J., and Rodriguez-Oreggia, E. (2012): «Regional Growth in Mexico Under Trade Liberalisation: How Important are Agglomeration and FDI?». The Annals of Regional Science 48, pp. 179-202. 
JordaAn, J., and Sanchez-Reaza, J. (2006): «Trade Liberalization and Location: Empirical Evidence for Mexican Manufacturing Industries 1980-2003». The Review of Regional Studies 36, pp. 279-303.

KIM, S. (2009): "Spatial Inequality and Economic Development: Theories, Facts, and Policies». Working Paper no. 16, Commission on Growth and Development, The World Bank.

Klein, A., and Crafts, N. (2012): "Making Sense of the Manufacturing Belt: Determinants of U.S. Industrial Location, 1880-1920». Journal of Economic Geography 12, pp. 775-807.

Krugman, P., and Livas-Elizondo, R. (1996): "Trade Policy and the Third World Metropolis». Journal of Development Economics 49, pp. 147-150.

Kuntz, S. (2002): «Nuevas series del comercio exterior de México, 1870-1929». Revista de Historia Económica XX (2), pp. 213-270.

KunTz, S. (2010): "De las Reformas Liberales a la Gran Depresión, 1856-1929», in S. Kuntz (ed.), Historia Económica General de México: de la Colonia a nuestros día. Mexico: El Colegio de México, pp. 305-352.

Kuntz, S. (2014): «The Contribution of Exports to the Mexican Economy during the First Globalisation (1870-1929)». Australian Economic History Review 54, pp. 95-119.

Kuntz, S., and Speckman, E. (2011): «El Porfiriato», in Nueva Historia General de México. Mexico: El Colegio de México, pp. 487-536.

Maddison, A. (1992): La economía mundial en el siglo XX. Rendimiento y política en Asia, América Latina, la URSS y los países de la OCDE Mexico: Fondo de Cultura Económica.

Marichal, C., and Cerutti, M. (1997): Historia de las grandes empresas en México, 1895-1930 Mexico: Fondo de Cultura Económica, Universidad Autónoma de Nuevo León.

Martínez-Galarraga, J. (2012): "The Determinants of Industrial Location in Spain, 1856-1929». Explorations in Economic History 49, pp. 255-275.

MoAsterio, L., and Reis, E. (2008): «Mudanças na concentraçao especial das ocupaços nas atividades manufatureiras no Brasil, 1872-1920». Working Paper no. 1361, Brazil: Instituto de Pesquisa Economica Aplicada.

Pérez, E. (1960): «El producto nacional». México: cincuenta años de revolución 1, pp. 571-592.

Rosés, R.; Martínez-Galarraga, J., and Tirado, D. (2010): «The Upswing of Regional Income Inequality in Spain (1860-1930)». Explorations in Economic History 47, pp. 244-257.

Ruiz, W. (2006): «Alcance del método de asignación geográfica relativa del producto, para construir una visión retrospectiva del crecimiento regional en México». Análisis Económico XXI, pp. 328-353.

Ruiz, W. (2007): «Convergencia Económica Interestatal en México, un Enfoque de Largo Plazo, 1900-2004». Universidad Autónoma de Madrid, Spain, PhD dissertation.

Ruiz, W. (2010): «Convergencia económica interestatal en México, 1900-2004». Análisis Económico XXV, pp. 7-34.

Ruiz, W. (2014): "Estimaciones quinquenales del PIB estatal industrial en México durante 1930-1965, a partir de información censal» Documento de Trabajo Spain: Asociación Española de Historia Económica. DT-AEHE No 1418.

Sánchez-Reaza, J., and Rodríguez-Pose, A. (2002): «The Impact of Trade Liberalization on Regional Disparities in Mexico". Growth and Change 33, pp. 72-90.

Solís, L. (1970): La economía mexicana, retrovisión y perspectivas Mexico: Fondo de Cultura Económica. 
Unikel, L.; Ruiz-Chiapetto, C., and Garza, G. (1978): México: Desarrollo urbano e implicaciones futuras Mexico: El Colegio de México.

\section{STATISTICAL SOURCES}

Banco de México (1962): «Producto Nacional Bruto por Actividades año de 1961 por Trimestres». Documento del Departamento de Estudios Económicos PN(E)/62/5.

Departamento de la Estadística Nacional (1925): Anuario Estadístico. Censo y Demografía, Vida Económica, y Vida Social y Moral. 1923-1924. Mexico City: Departamento De La Estadística Nacional.

Departamento de la Estadística Nacional: Bulletin of National Statistics: 1921, 1930. Departamento De La Estadística Nacional.

Dirección General de Estadística (DGE) (1956): Estadísticas Sociales del Porfiriato 1877-1910. Mexico City: DGE.

Dirección General de Estadística (DGE): Statistical Year Book: 1893, 1895, 1900, 1905, 1907. Mexico City: DGE.

Dirección General de Estadística (DGE): Industrial Census: 1930, 1935, 1960. Mexico City: DGE.

Dirección General de Estadística (DGE): Population Census: 1895, 1900, 1910, 1921, 1930, 1940. Mexico City: DGE.

Dirección General de Estadística (DGE) (1903): Estadística Industrial de 1902. Mexico City: DGE.

Dirección General de Estadística (DGE): First Census of Agriculture and Livestock: 1930. Mexico City: DGE.

El Colegio de Mexico (1964): Estadísticas Económicas del Porfiriato: Fuerza de trabajo y actividad económica por sectores. Mexico City: El Colegio de Mexico.

Instituto Nacional de Estadística y Geografía (INEGI) (1985): Sistema de Cuentas Nacionales. Estructura Económica Regional, Producto Interno Bruto: 1970, 195, 1980. Mexico City: INEGI.

Instituto Nacional de Estadística y Geografía (INEGI) (2009): Estadísticas Históricas de México. Mexico City: INEGI.

Secretaría de Estado y del Despacho de Hacienda y Crédito Público: Fiscal Statistics Bulletins: 1895, 1900, 1910. Mexico City: Secretaría de Estado y del Despacho de Hacienda y Crédito Público.

Secretaría de Industria, Comercio y Trabajo: Mining Statistical Year Book: 1923, 1927. Mexico City: Secretaría de Industria, Comercio y Trabajo. 